\title{
Experiências de participação da Universidade Federal de Itajubá nas políticas públicas de resíduos sólidos urbanos e suas contribuições para o desenvolvimento local sustentável
}

\section{Simone Alves Alexandrino ${ }^{1}$, Daniela Rocha Teixeira Riondet-Costa ${ }^{1}$, Márcia da Conceição Pereira Alves ${ }^{2}$}

\author{
${ }^{1}$ Universidade Federal de Itajubá. Instituto de Recursos Naturais. Av. BPS, no 1303 , \\ Bloco L8. Pinheirinho. Itajubá-MG, Brasil (CEP 37500-903). E-mail: \\ simonealexandrino@unifei.edu.br, \\ ${ }^{2}$ Faculdade de Ciências Sociais Aplicadas do Sul de Minas. Av. Pres. Tancredo de \\ Almeida Neves, 45. Bairro Avenida. Itajubá-MG, Brasil (CEP 37504-066).
}

\begin{abstract}
Resumo. Partindo-se da noção de desenvolvimento local sustentável como um conjunto de iniciativas que reforçam a constituição de valores éticos e o sentimento de corresponsabilização pelas condições socioeconômicas e ambientais de um determinado lugar, o objetivo geral desta pesquisa foi conhecer como são as experiências de participação da Universidade Federal de Itajubá (UNIFEI) nas políticas públicas de resíduos sólidos urbanos (RSU) e suas contribuições para o desenvolvimento local sustentável. A pesquisa possui uma abordagem qualitativa do tipo descritiva que se restringe ao recorte temporal para coleta de dados do período compreendido entre os anos 2014 e 2016. Os procedimentos de coleta de dados foram pesquisa bibliográfica, pesquisa documental, observação participante e diário de campo. 0 objeto da pesquisa foi delimitado a cinco grupos de amostras de experiências de participação da UNIFEI nas políticas públicas de RSU: o diagnóstico socioeconômico dos catadores de materiais recicláveis autônomos, o projeto "Vitória Consciente", o projeto "Itajubá de Olho no Óleo", a audiência pública para elaboração do Plano Municipal de Saneamento e outros projetos de pesquisa e extensão relacionados aos RSU. Para a análise e discussão das contribuições que as experiências de participação trouxeram para o processo de desenvolvimento local sustentável foi utilizada a técnica da matriz de impacto das ações. A relevância desta pesquisa reside na necessidade de reflexão sobre papel da universidade na sociedade, não só como instituição formadora de profissionais capazes de promoverem a cidadania, mas também como ator coadjuvante do processo de desenvolvimento local sustentável por oferecer condições favoráveis para a realização de intervenções sociais e práticas educativas em RSU que impactam na qualidade de vida das pessoas e no meio ambiente da região em que está inserida.
\end{abstract}

Recebido: $09 / 07 / 2018$

Aceito: $29 / 08 / 2018$

Publicado: $31 / 08 / 2018$

Acesso aberto

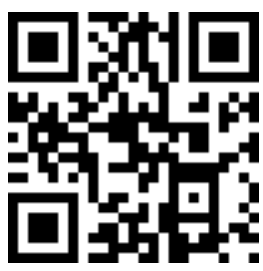

ORCID

(1) 0000-0001-7654-2576 Simone Alves Alexandrino

(D) 0000-0001-9355-6056 Daniela Rocha Teixeira Riondet-Costa

(D) 0000-0003-3509-3828 Márcia da Conceição Pereira Alves 
Palavras-chave: Participação; Universidade; Políticas públicas. Resíduos sólidos urbanos; Desenvolvimento local sustentável.

\section{Abstract. Experiences of participation of the Federal University of Itajubá in the public policies of urban solid waste and their contributions to sustainable local development.} Based on the notion of sustainable local development as a set of initiatives that reinforce the ethical values and the sense of coresponsibility for the socioeconomic and environmental conditions of a given place, the general objective of this research was to know the experiences of Federal University of Itajubá (UNIFEI) in the public policies of solid urban waste (SUW) and its contributions to sustainable local development. The research has a qualitative approach of the descriptive type that is restricted to the temporal cut-off for data collection between the years 2014 and 2016. The procedures of data collection were bibliographic research, documentary research, participant observation and field diary. The objective of the research was delimited to five groups of samples of UNIFEI participation experiences in the public policies of SUW: the socioeconomic diagnosis of collectors of autonomous recyclable materials, the project "Vitória Consciente", the project "Itajubá de Olho no Óleo", the public hearing for the preparation of the Municipal Sanitation Plan and other research and extension projects related to SUW. For the analysis and discussion of the contributions that the experiences of participation brought to the process of sustainable local development was used the technique of the matrix of impact of the actions. The relevance of this research lies in the need to reflect on the role of the university in society, not only as an institution to train professionals capable of promoting citizenship, but also as a supporting actor in the process of sustainable local development by offering favorable conditions for social interventions and educational practices in MSW that impact the quality of life of people and the environment of the region in which it is inserted.

Keywords: Participation; University; Public policy; Urban solid waste; Sustainable local development.

\section{Introdução}

A história mostra que para atender necessidades básicas de sobrevivência os homens reuniam-se para a caça de alimentos e mútua proteção contra os perigos existentes na natureza. Com o passar dos tempos a formação de cidades para atender às necessidades dadas pela natureza, pelo comércio e pelas linhas de defesa militar tornou essa reunião um fenômeno social complexo e envolto de problemas oriundos do adensamento populacional (Guattari, 1990).
Como fenômenos sociais, as cidades, mesmo que sejam planejadas, tendem a crescer desordenadamente a partir de demandas produtivas e das migrações que as atingem. Quanto mais se adensa a população, mais se intensificam os problemas sociais, econômicos, políticos e ambientais que as acometem em decorrência da compressão demográfica característica dos centros urbanos. Por isso, as cidades têm se tornado um lugar onde os problemas socioambientais aparecem com mais nitidez, onde a pobreza e as 
desigualdades mostram sua face e os dejetos e resíduos domésticos e industriais atingem as águas, o ar, o solo e a saúde dos habitantes (IPEA, 2010).

São nas cidades também que se encontram as instituições políticas e científicas que influenciam o processo de tomada de decisões individuais e coletivas que são capazes de influenciar o processo de desenvolvimento local de maneira sustentável ou não, especialmente em relação a um problema complexo que atinge toda a sociedade em várias dimensões relacionadas entre si como é caso dos Resíduos Sólidos Urbanos (RSU).

Nesse contexto, as universidades brasileiras têm realizado uma diversificada gama de experiências de participação nas políticas públicas de RSU que tem contribuído para o processo de desenvolvimento local tanto por meio da educação ambiental, quanto por meio da realização de projetos vinculados ao avanço da ciência e tecnologia. Conhecer essas experiências e estudá-las pode constituir uma via de mão dupla onde todos ganham, já que

\begin{abstract}
as universidades que se fecham entre quatro paredes fenecem, pois perdem os dados do mundo circundante que as alimentam e as problematizam, propiciando a produção do conhecimento (Aguiar, 2002).
\end{abstract}

Partindo de um referencial teórico que dialoga com os conceitos e fundamentos que constituem o universo interdisciplinar dos temas "desenvolvimento sustentável" e "políticas públicas de resíduos sólidos urbanos" esta pesquisa problematiza a seguinte questão: "como são as experiências de participação da Universidade Federal de Itajubá (UNIFEI) nas políticas públicas de resíduos sólidos urbanos e suas contribuições para o desenvolvimento local sustentável?".

Preliminarmente, tomou-se por hipótese que a UNIFEI participa dessas políticas apenas de maneira instrumental atendendo às exigências de editais de pesquisa de cunho tecnológico e convênios públicos para a prestação de serviços técnicos especializados, sem, contudo, se relacionar afetivamente com a sociedade civil para juntos empreenderem ações relacionadas com as problemáticas locais que envolvem os RSU.

0 que justifica a realização desta pesquisa é o fato de a UNIFEI representar um importante agente do desenvolvimento científico, tecnológico, cultural e socioeconômico no Município de Itajubá, Estado de Minas Gerais. A instituição é a única universidade federal nessa microrregião e a sua comunidade universitária representa cerca de $10 \%$ da população estimada do município, oferecendo, portanto, condições singulares capazes de influenciar os diversos agentes do desenvolvimento.

Ao participar das políticas públicas de RSU a universidade caminha no mesmo sentido da sua missão institucional, pois promove o retorno social dos investimentos públicos na educação superior e utiliza conhecimentos multidisciplinares para realizar ações que contribuam para a sensibilização e formação crítica humanística dos futuros profissionais que poderão representar agentes fundamentais para o processo de mudança dos paradigmas do desenvolvimento em qualquer região do país ou do mundo.

Além da importância da UNIFEI para o processo de desenvolvimento local sustentável, o direcionamento da pesquisa às políticas públicas de RSU no Município de Itajubá tem por base os estudos de Pinheiro (2005) que ao fazer uma avaliação histórica das enchentes constatou que o lixo urbano é um dos fatores que mais colaboram para a degradação do potencial paisagístico da cidade, prejudica a saúde da população devido à proliferação dos vetores transmissores de doenças e concorre para o agravamento das enchentes, que, inclusive, atingem o campus universitário da UNIFEI. 
Itajubá está situada no sul do estado de Minas Gerais, às margens do Rio Sapucaí, na Serra da Mantiqueira. É considerada uma cidade com posição estratégica para o escoamento de bens e serviços por estar localizada entre duas das mais importantes rodovias do país, a Fernão Dias e a Presidente Dutra. A cidade possui cinquenta e sete bairros e exerce influência direta sobre quatorze municípios da microrregião. Sua população equivale a $0,47 \%$ da população mineira. Além disso, conta com um elevado número de indústrias que atraem grandes investimentos públicos e privados (Itajubá, 2016).

Outro fator que justifica a pertinência deste estudo é o Consórcio Intermunicipal dos Municípios da Microrregião do Alto Sapucaí para Aterro Sanitário (CIMASAS) que é constituído por seis municípios, Itajubá, São José do Alegre, Piranguinho, Piranguçu, Delfim Moreira e Wenceslau Braz. Criado em 2007, o CIMASAS foi o primeiro consórcio formado por municípios no Estado de Minas Gerais (Santos, 2014). Antes mesmo de entrar em vigor a Lei $\mathrm{n}^{\mathbf{0}}$ 12.305/2010, que instituiu a Política Nacional de Resíduos Sólidos (PNRS), Itajubá já atendia à obrigatoriedade imposta pela PNRS de que os municípios encerrassem os lixões, dessem destinação final ambientalmente adequada aos RSU e organizassem os catadores em cooperativas de trabalho (Brasil, 2010).

Em decorrência da construção do aterro sanitário em Itajubá/MG foi possível o encerramento das atividades do lixão municipal e os catadores que ali trabalhavam foram reunidos na Associação dos Catadores Itajubenses de Materiais Recicláveis (ACIMAR) que é uma das associações de economia solidária que recebe assessoria técnica e financeira da Incubadora Tecnológica de Cooperativas Populares (INTECOOP) da UNIFEI, desde 2007, para realizar os serviços de coleta seletiva municipal.

Porém, apesar de tudo isso, Itajubá ainda não conseguiu efetivar o sistema de coleta seletiva residencial e apenas $6 \%$ dos resíduos recicláveis estão sendo recolhidos pela ACIMAR. De acordo com Moura (2014), a quantidade média de resíduos que foram destinados ao aterro sanitário em 2010 foi de $1.439 .487 \mathrm{~kg}$ e, em 2013, a quantidade média aumentou para $1.705 .658 \mathrm{~kg}$.

Ou seja, dentro de três anos houve um aumento de $18 \%$ na quantidade dos RSU gerados pela população, indo na contramão do objetivo estipulado pela PNRS que é a elevação das escalas de aproveitamento e a redução dos custos envolvidos na gestão dos RSU. Os altos custos com a manutenção do aterro sanitário tem sido assunto de debates em audiências públicas e o município ainda não possui um programa oficial de educação ambiental que sensibilize a população sobre a responsabilidade compartilhada de todos pelo ciclo de vida dos RSU gerados.

Considerando as peculiaridades que envolvem as políticas públicas de RSU no Município de Itajubá, Estado de Minas Gerais, e os reflexos socioambientais deles advindos é que se identificou a necessidade do enfrentamento dessa questão sob o prisma de uma pesquisa interdisciplinar que se propõe a conhecer em profundidade e criticidade como são as experiências de participação da UNIFEI nessas políticas e quais as suas contribuições para o processo de desenvolvimento local sustentável.

\section{A Política Nacional de Resíduos Sólidos (PNRS) e seus instrumentos}

De acordo com o art. 6으, da Lei no $12.305 / 2010$, a PNRS é uma política de desenvolvimento sustentável que deve ter uma visão sistêmica das problemáticas que envolvem os resíduos sólidos considerando suas variáveis ambiental, social, cultural, econômica, tecnológica e de saúde pública (Brasil, 2010).

De acordo com esse artigo, o reconhecimento dos resíduos recicláveis 
como um bem econômico, a incorporação do princípio ambiental do poluidorpagador e protetor-recebedor que responsabiliza os fabricantes pela logística reversa dos produtos poluentes colocados no mercado e o princípio da ecoeficiência dos produtos e serviços são alguns exemplos de princípios que fazem parte da esfera econômica que envolve os RSU. E essa prudência ecológica vinculada aos resíduos que são colocados no mercado constitui um dos pilares econômicos do desenvolvimento sustentável:

[...] em muitos casos, a prudência ecológica se autofinancia até em termos econômicos tradicionais. Por exemplo, a transformação do lixo em riqueza, através de reciclagem, composição ou extração de energia, pode vir a ser um empreendimento lucrativo (Sachs, 1986, p. 71).

Do ponto de vista ambiental, a PNRS prevê a obrigatoriedade de instalação e operação de aterros sanitários que respeitem as normas técnicas e a legislação ambiental vigente como um compromisso com a mitigação dos impactos ambientais:

\begin{abstract}
Art. 3o Para os efeitos desta Lei, entende-se por:

VIII - disposição final ambientalmente adequada: distribuição ordenada de rejeitos em aterros, observando normas operacionais específicas de modo a evitar danos ou riscos à saúde pública e à segurança e a minimizar os impactos ambientais adversos; (Brasil, 2010).
\end{abstract}

Em seu art. 54, a PNRS havia concedido um prazo de quatro anos para que os 5.570 municípios implantassem os aterros sanitários na forma da lei. No entanto, o prazo terminou em agosto de 2014 e quase 3.000 municípios e o Distrito Federal ainda não conseguiram cumprir as determinações da PNRS com o fechamento e tratamento dos lixões, a inclusão social dos catadores e a coleta seletiva municipal (Senado, 2015).
No entanto, a instalação e operação de um aterro sanitário, por si só, não é capaz de atender a todas as variáveis do desenvolvimento sustentável que envolvem os RSU. Por isso, para concretizar os princípios que lhe embasam, o art. 8o, da PNRS prevê instrumentos para a gestão dos RSU, e, dentre eles, destacam-se:

a) Os Planos de Resíduos Sólidos

o plano nacional de resíduos sólidos, os planos estaduais, microrregionais, intermunicipais, municipais e individuais são instrumentos de realização da PNRS. A ideia envolve a realização de um inventário prospectivo dos resíduos a serem eliminados em escala, com certo número de prioridades na gestão dos resíduos, considerando as metas para sua redução e eliminação de forma cooperativa e articulada entre o poder público, o mercado e a sociedade (Lemos, 2012).

Destaca-se que o parágrafo único, do art. 8º, impõe a obrigatoriedade de ser assegurada "ampla publicidade" ao conteúdo dos planos de resíduos sólidos, bem como o controle social em sua formulação, implementação e operacionalização (Brasil, 2010).

Além disso, o art. 18, da PNRS determina que a elaboração dos planos municipais seja condição para que os municípios tenham acesso a recursos da União destinados a empreendimentos e serviços relacionados à limpeza urbana, ao manejo de resíduos sólidos e para serem beneficiados por incentivos ou financiamentos de entidades federais de crédito ou fomento para tal finalidade (Brasil, 2010).

Terão prioridade no acesso aos recursos da União os municípios que optarem por soluções consorciadas intermunicipais para a gestão de resíduos sólidos e que implantarem a coleta seletiva municipal com participação de cooperativas de catadores de materiais recicláveis formadas por pessoas físicas de baixa renda (Brasil, 2010). 
0 art. 19 relaciona o conteúdo mínimo que os Planos Municipais de Gestão Integrada de Resíduos Sólidos (PMGIRS) devem conter, ressaltando-se o diagnóstico da situação dos resíduos gerados; os indicadores de desempenho operacional e ambiental dos serviços públicos de limpeza urbana; os programas e ações de educação ambiental que promovam a não geração, a redução, a reutilização e a reciclagem de resíduos; os mecanismos para a criação de fontes de negócios, emprego e renda, mediante a valorização dos resíduos sólidos; metas de redução, reutilização, coleta seletiva e reciclagem, entre outras (Brasil, 2010).

\section{b) A Coleta Seletiva Municipal}

A coleta seletiva é a coleta de resíduos sólidos previamente segregados conforme sua constituição ou composição. Esse sistema reduz a quantidade de lixo que precisa ser coletado e tratado em aterros sanitários reduzindo os custos de transporte e destinação final ambientalmente adequado (Abreu, 2008).

O Decreto no 7.404/2010, regulamenta a Lei $\mathrm{n}^{0}$ 12.305/2010, que institui a PNRS e o seu art. 9o dispõem que o sistema de coleta seletiva deve ser implantado pelo titular do serviço público de limpeza urbana e manejo de resíduos sólidos constituindo-se em uma obrigação municipal. Nos sistemas de coleta seletiva deve ser priorizada a participação de associações de catadores de materiais recicláveis constituídas por pessoas de baixa renda (Brasil, 2010).

No entanto, por se tratar de prestação de serviço público, a operação do sistema de coleta seletiva municipal pode ser realizada de forma direta pelo poder público local ou indiretamente por meio de concessão, consórcio ou cooperação técnica, nos termos da Lei $\mathrm{n}^{\circ}$ 11.107/2005 (Brasil, 2005).

Mas mesmo com instrumentos legais que viabilizem a parceria entre município e iniciativa privada para a concretização dos sistemas de coleta seletiva, a sustentabilidade desses sistemas de coleta seletiva encontra muitos desafios para a sua implementação:

No Brasil, os programas de coleta seletiva são geralmente subsidiados pelo poder público e não apresentam sustentabilidade. Assim, além de recursos dos geradores, para que esta sustentabilidade seja atingida, se faz necessário, no mínimo, o programa apresentar escala de produção, regularidade na entrega (separação) e na coleta e um mercado para aproveitamento desses materiais. Os programas de educação e comunicação social são fundamentais para a continuidade das ações e o controle social indispensável para a duração e efetividade do sistema de coleta seletiva implantado. (GRS/UFPE, 2014, p. 47). (Sem grifos no original).

Desde 1994 o Compromisso Empresarial para Reciclagem (Cempre, 2016) reúne informações sobre programas de coleta seletiva por meio de uma pesquisa com abrangência nacional e periodicidade bianual de coleta de dados. De acordo com o órgão, a última pesquisa realizada pela associação em 2016, acusou que apenas 1.055 municípios brasileiros (cerca de $18 \%$ do total) operam programas de coleta seletiva.

c) A responsabilidade compartilhada pelo ciclo de vida dos produtos

É importante distinguir responsabilidade pelo gerenciamento dos RSU da responsabilidade compartilhada pelo ciclo de vida dos produtos. 0 gerenciamento dos RSU constitui responsabilidade do governo municipal e envolve uma sequência de atividades que auxiliam a melhoria do sistema de limpeza urbana, abrangendo a redução, reutilização e reciclagem (3R); o acondicionamento; a coleta e transporte dos resíduos; a limpeza dos logradouros; o tratamento (compostagem, reciclagem, digestão anaeróbia, incineração, etc); os 
programas de educação ambiental e a disposição final (aterros sanitários) (GRS/UFPE, 2014).

Diferentemente,

responsabilidade compartilhada pelo ciclo de vida dos produtos é um conjunto de atribuições individualizadas e encadeadas dos fabricantes, importadores, distribuidores e comerciantes, dos consumidores e dos titulares dos serviços públicos de limpeza urbana e de manejo dos resíduos sólidos, para minimizar o volume de resíduos sólidos e rejeitos gerados, bem como para reduzir os impactos causados à saúde coletiva e à qualidade ambiental decorrentes do ciclo de vida dos produtos (Brasil, 2010). Nesse cenário, não só o fabricante, mas o comerciante e o consumidor, também são responsáveis por dar a destinação adequada aos RSU que consomem ou comercializam.

d) 0 incentivo à criação e ao desenvolvimento de cooperativas ou de outras formas de associação de catadores de materiais reutilizáveis e recicláveis

0 universo social que envolve o fim dos lixões e a criação dos aterros sanitários é formado, sobretudo, por catadores de materiais recicláveis e pela população que vive no entorno dos locais de destinação final de resíduos. (Romani, 2007).

Dentre os diversos fatores sociais que se beneficiam com a construção, manutenção e operação do aterro sanitário destacam-se:

a) contribuição para geração líquida de empregos: por meio da coleta seletiva que envolva os catadores locais ou da instalação de uma unidade de triagem de materiais recicláveis com agregação de valor;

b) contribuição para a distribuição de renda: a geração de trabalho e o aumento da renda da população que vive "no" e "do" "lixo", por meio de sua qualificação e inserção no mercado de trabalho, direta ou indiretamente relacionado ao empreendimento. As melhorias nas condições de vida desses indivíduos, a partir de sua inserção no mercado de trabalho, podem ocorrer de forma articulada à inclusão dos mesmos em programas sociais do governo;

c) contribuição para capacitação $e$ desenvolvimento tecnológico: o treinamento profissional de brasileiros para operação e manutenção de equipamentos e desenvolvimento de tecnologias limpas que maximizem o potencial de reciclagem dos resíduos pode, num futuro próximo, evitar a contratação de mão de obra e assistência técnica internacional.

d) contribuição para a integração regional e articulação com outros setores: este item pode ser visto por duas vertentes: uma com foco na articulação setorial envolvendo o poder público municipal, as instituições públicas e privadas e demais organizações da sociedade não governamentais (ONGs) - e outra com foco na regionalização de compromissos e benefícios. A articulação setorial pode ocorrer quando o processo de implementação do aterro envolva a contratação de uma ONG, associação ou cooperativa que aqueça a economia local. 0 fortalecimento da integração regional pode ocorrer por meio de consorciamento entre um ou mais municípios para a instalação e operação do aterro sanitário. (Romani, 2007, p. 16-18).

Por isso, o incentivo à criação e ao desenvolvimento de cooperativas ou de outras formas de associação de catadores de materiais recicláveis contribui para a inclusão socioeconômica dessa classe trabalhadora e para a redução do impacto ambiental dos RSU. Trata-se de promover o respeito à natureza com maior equidade social, transformando o que não tem valor para uma classe em fonte de renda para outra (Romani, 2007).

0 art. 11, do Decreto $\mathrm{n}^{\mathrm{o}}$ 7.404/2010 (Brasil, 2010), estabelece que o sistema de coleta seletiva deve 
priorizar a participação de cooperativas ou outras formas de associação de catadores constituídas por pessoas físicas de baixa renda. (Brasil, 2010). Mas, de acordo com a Cempre (2016) dos 1055 municípios que possuem programa de coleta seletiva em funcionamento, apenas $44 \%$ mantém cooperativas de catadores como agentes executores da coleta seletiva municipal.

e) A cooperação técnica e financeira entre os setores público e privado para o desenvolvimento de pesquisas

Atualmente existem diversos tipos de tratamentos físicos, químicos e biológicos que têm por objetivo diminuir a poluição do meio ambiente, reduzir os impactos sanitários negativos na sociedade e o beneficiamento econômico do resíduo. No Brasil predomina o tratamento e destinação final dos RSU em aterros sanitários, embora ainda exista uma enorme quantidade de lixões em descumprimento às determinações da PNRS (GRS/UFPE, 2014).

Porém, os aterros sanitários têm se mostrado empreendimentos caros e complexos que exigem o domínio de várias áreas do conhecimento e o uso de diversas tecnologias:

Em um aterro sanitário existem diversos elementos que devem ser projetados e planejados com base em critérios de engenharia, tais como sistema de impermeabilização de base, sistema de drenagem de águas superficiais, drenagem de líquidos e gases gerados na decomposição da massa de resíduos, sistema de cobertura dos resíduos, unidades de tratamento de lixiviados e outros. Esse conjunto de sistemas e unidades visa garantir a segurança do aterro, o controle de efluentes líquidos, a redução das emissões gasosas, bem como a redução de riscos à saúde da população, garantindo assim o correto recebimento e tratamento dos resíduos, com menor impacto ambiental e proteção da saúde pública. (GRS/UFPE, 2014, p. 63).
De acordo com Romani (2007) a implantação de programas de coleta seletiva incentiva o desvio de materiais inorgânicos que seriam encaminhados aos aterros sanitários, maximizando as chances de o empreendimento gerar biogás. Por isso, a PNRS prevê como instrumento para a sua concretização a cooperação técnica e financeira entre os setores público e privado para o desenvolvimento de pesquisas e tecnologias relacionadas à gestão dos RSU. Porém, tudo isso desvencilhado da educação ambiental torna-se um trabalho excessivamente oneroso.

f) A educação ambiental e a pesquisa científica e tecnológica

A educação ambiental pode ser definida como "um processo informativo e formativo dos indivíduos que, desenvolvendo habilidades e modificando atitudes em relação ao meio em que vivem, torna a comunidade educativa consciente de sua realidade global" (Soares et al., 2007).

Como visto, o art. 19 da PNRS dispõe que os planos de resíduos sólidos devem prever programas e ações de educação ambiental que promovam a não geração, a redução, a reutilização e a reciclagem dos resíduos, sendo esse um instrumento fundamental para a continuidade das ações e o controle social indispensável para a duração e efetividade do sistema de coleta seletiva implantado (Brasil, 2010).

No mesmo sentido, o art. 77 , do Decreto $\mathrm{n}$ o 7.404/2010, diz que a educação ambiental na gestão dos RSU tem como objetivo o aprimoramento do conhecimento, dos valores, dos comportamentos e do estilo de vida relacionados com a gestão e o gerenciamento ambientalmente adequado dos resíduos (Brasil, 2010).

Para concretizar os programas e ações de educação ambiental, o $\S 2^{\circ}$, do art. 77, do Decreto no 7.404/2010, impõe ao Poder Público o dever de incentivar atividades de caráter educativo e pedagógico em colaboração com entidades do setor empresarial e da 
sociedade civil organizada e apoiar as pesquisas científicas e tecnológicas realizadas por órgãos oficiais, pelas universidades, por organizações não governamentais e por setores empresariais, bem como, a elaboração de estudos, a coleta de dados e de informações sobre o comportamento do consumidor brasileiro (Brasil, 2010).

g) Os órgãos colegiados municipais destinados ao controle social dos serviços de RSU

A participação política que ocorre durante as eleições para governantes e legisladores não é suficiente para consolidar o elevado grau de participação popular que uma democracia exige para a legitimação dos processos decisórios da administração pública, "uma vez que os reais interesses públicos são ainda, em maioria, ideais não alcançados" (Tenório, 1997).

Habermas (1998, p. 385) defende a participação como um caminho para a cidadania deliberativa, onde a sua prática é baseada na correlação entre direitos humanos e soberania popular levadas em consideração em todas as suas formas de comunicação morais, éticas, pragmáticas e de negociação. Nessa perspectiva, a cidadania deliberativa constitui-se em uma forma de articulação onde qualquer indivíduo pode se expressar e questionar as prerrogativas unilaterais de ação política do poder (seja ele público ou privado). Nesse sentido, os órgãos colegiados municipais destinados à participação e ao controle social são espaços de cidadania deliberativa onde a população pode identificar, compreender, problematizar e propor soluções aos problemas da comunidade (Tenório, 2007).

Esses órgãos colegiados municipais destinados ao controle social dos serviços de RSU se amoldam aos fundamentos do desenvolvimento local sustentável onde a sociedade civil informada discute as prioridades que devem ser contempladas e a legitimidade das decisões políticas em relação às necessidades impostas pela realidade de onde vivem.

Assim, cabe à população conhecer e exigir que sejam adotadas todas as medidas para que os planos de resíduos sólidos sejam implementados em nível local, "entretanto, a lei não previu mecanismos específicos de controle da implementação dos planos de gestão, 0 que parece extremamente importante no caso" (Lemos, 2012).

No Município de Itajubá o Comitê Gestor da Coleta Seletiva Municipal está em funcionamento desde novembro de 2014. Por meio da observação participante foi possível constatar que o referido comitê não possui regularidade em suas reuniões, tendo realizado até junho de 2016 apenas quatro reuniões para discutir ações específicas como a realização do diagnóstico socioeconômico dos catadores de materiais recicláveis do município. Suas reuniões não são divulgadas para a população e ocorrem dentro das dependências da Prefeitura. Também não são registradas atas das reuniões para serem amplamente divulgadas. Atualmente, são em torno de quatorze os membros participantes, sendo que oito deles possui algum vínculo com a UNIFEI (professor, aluno ou ex-aluno).

\section{Método de Pesquisa}

Do ponto de vista metodológico, esta pesquisa possui uma abordagem qualitativa do tipo descritiva que se restringe ao recorte temporal para coleta de dados ao período compreendido entre os anos 2014 e 2016. Os procedimentos de coleta de dados foram pesquisa bibliográfica, documental, observação participante e o diário de campo. Para a análise e discussão das experiências de participação da UNIFEI nas políticas públicas de RSU e suas contribuições para o processo de desenvolvimento local sustentável foi utilizada a técnica qualitativa da matriz de impacto das ações, proposta por Buarque (2008) como metodologia de planejamento do desenvolvimento. 


\section{Resultados e discussão}

\section{Identificação das políticas públicas de RSU do município de Itajubá/MG}

Para identificar as políticas públicas de RSU do município de Itajubá/MG foi realizado um levantamento documental por meio do website oficial da Prefeitura e da Câmara Legislativa Municipal, com a busca pelas palavras-chave: coleta, resíduo, sólido, lixo e reciclagem (Tabela 1 ).

Tabela 1. Identificação das políticas públicas de RSU do município de Itajubá.

\begin{tabular}{|c|c|}
\hline & $\begin{array}{l}\text { no 3.129/2015: Dispõe sobre a obrigatoriedade de recolhimento de resíduos fecais de } \\
\text { mais conduzidos em espaços públicos e dá outras providências. }\end{array}$ \\
\hline 02 & $\begin{array}{l}\text { Lei no 3.066/2014: Declara de Utilidade Pública Municipal a Associação de Catadores } \\
\text { Autônomos de Reciclagem Itajubense - ACARI. }\end{array}$ \\
\hline 03 & $\begin{array}{l}\text { Lei no 3.039/2014: Autoriza o Município de Itajubá a doar bens móveis do patrimônio } \\
\text { municipal à ACIMAR e à ACARI - Associações de Catadores de Materiais Recicláveis de Itajubá. }\end{array}$ \\
\hline 04 & $\begin{array}{l}\text { Lei } \mathrm{n}^{\circ} \text { 2.987/2013: Revoga lei municipal } \mathrm{n}^{-} \text {2.861, de } 23 / 09 / 2011 \text {, que dispõe sobre a } \\
\text { substituição do uso de saco plástico de lixo e de sacola plástica por saco de lixo e sacolas } \\
\text { ecológicas. }\end{array}$ \\
\hline 05 & $\begin{array}{l}\text { Lei no 2.940/2012: Dispõe sobre medida de reaproveitamento de óleo vegetal (cozinha) e } \\
\text { seus resíduos, e dá outras providências. }\end{array}$ \\
\hline 06 & $\begin{array}{l}\text { Lei no } 2.928 / 2012 \text { : Dispõe sobre a obrigatoriedade de condomínios e os edifícios residenciais } \\
\text { com mais de dez unidades habitacionais a manterem em suas dependências recipientes } \\
\text { destinados à separação de lixo orgânico e inorgânico. }\end{array}$ \\
\hline 07 & $\begin{array}{l}\text { Lei } \mathrm{n}^{0} \text { 2.917/2012: Institui o Dia do Reciclador e da Reciclagem de Lixo no município de } \\
\text { Itajubá, e dá outras providências. }\end{array}$ \\
\hline 08 & $\begin{array}{l}\text { Lei no 2.886/2011: Regulamenta a coleta de medicamentos com prazos de validade vencidos } \\
\text { no município de Itajubá, até sua disposição final como resíduo sólido urbano. }\end{array}$ \\
\hline 09 & $\begin{array}{l}\text { Lei } \mathrm{n}^{0} \text { 2.692/2008: Declara de utilidade pública municipal a associação dos catadores de } \\
\text { materiais recicláveis. }\end{array}$ \\
\hline 10 & $\begin{array}{l}\text { Lei } \mathrm{n}^{\mathrm{o}} \text { 2.626/2007: Institui o projeto socioambiental de coleta seletiva de produtos } \\
\text { recicláveis, sua destinação e dá outras providências. }\end{array}$ \\
\hline 11 & Lei no 2.538/2005: Institui a Semana da Reciclagem do Lixo no Município de Itajubá. \\
\hline 12 & Lei no 1.672/1988: Dispõe sobre acondicionamento, coleta e destinação final do lixo de risco. \\
\hline 13 & $\begin{array}{l}\text { Lei } \mathrm{n}^{\mathrm{o}} 1.2 \\
\text { Concessão }\end{array}$ \\
\hline
\end{tabular}

Analisando esses documentos observou-se que existem treze normas municipais que regulamentam políticas de RSU. Desse total, três leis estão relacionadas às associações de catadores de materiais recicláveis; cinco leis tratam especificamente de diferentes tipos de RSU (lixo hospitalar, medicamentos vencidos, óleo de cozinha, sacolas plásticas e resíduos fecais de animais) e as outras cinco leis municipais regulamentam assuntos relacionados ao dia da reciclagem, a coleta de lixo urbano e a coleta seletiva domiciliar.

Foi constatado que existem diversas leis municipais regulamentando políticas relacionadas aos RSU, mas nenhuma dessas normas institui o Plano Municipal de Gestão Integrada de Resíduos Sólidos (PMGIRS), garantindo o controle e a participação social durante a sua formulação, implementação e operacionalização, conforme determina o art. $8^{\circ}$, da PNRS. 
Apesar de não ter sido encontrado o PMGIRS no website oficial da Prefeitura e nem da Câmara Legislativa Municipal, de acordo a
Tabela 2, o Município de Itajubá declara possuir o PMGIRS, nas seguintes condições:

Tabela 2. Planilha dos municípios que declararam possuir o PMGIRS.

\begin{tabular}{|c|c|c|c|c|c|}
\hline \multicolumn{2}{|c|}{ 9. Variáveis externas } & \multicolumn{3}{|c|}{$\begin{array}{l}\text { 7.4 Parceria com Governo Federal, Comissão Interinstitucional de Educação } \\
\text { Ambiental (CIEA) e Plano de Gestão Integrada de Residuos Sólidos }\end{array}$} & \multirow{2}{*}{\begin{tabular}{|c|}
$\begin{array}{c}5.5 \\
\text { Instrumentos de } \\
\text { planejamento }\end{array}$ \\
Plano de Saneamento \\
Básico contemplando o \\
serviço de limpeza \\
urbana e manejo de \\
resíduos sólidos
\end{tabular}} \\
\hline Nome do município & $\begin{array}{l}\text { População } \\
\text { estimada } \\
2013^{*}\end{array}$ & $\begin{array}{l}\text { Educação Ambiental no } \\
\text { Plano de Gestão de } \\
\text { Resíduos Sólidos }\end{array}$ & $\begin{array}{l}\text { O município possui Plano de Gestão } \\
\text { Integrada de Resíduos Sólidos nos } \\
\text { termos estabelecidos na Política } \\
\text { Nacional de Resíduos Sólidos }\end{array}$ & $\begin{array}{l}\text { Esse plano abrange } \\
\text { apenas esse } \\
\text { município }\end{array}$ & \\
\hline ITABIRITO & 48.614 & Sim & Não & Não aplicável & Sim \\
\hline ITACAMBIRA & 5.241 & Não aplicável & Não & Não aplicável & Não aplicável \\
\hline ITACARAMBI & 18.316 & Sim & Não & Não aplicável & Não aplicável \\
\hline ITAGUARA & 12.999 & Não aplicável & Não & Não aplicável & Sim \\
\hline ITAIPE & 12.403 & Não aplicável & Não & Não aplicável & Não \\
\hline ITAJUBA & 94.940 & Não & Sim & Não & Não aplicável \\
\hline ITAMARANDIBA & 33.804 & Não aplicável & Não & Não aplicável & Não aplicável \\
\hline ITAMARATI DE MINAS & 4.270 & Não aplicável & Não & Não aplicável & Não aplicável \\
\hline ITAMBACURI & 23.528 & Não aplicável & Não & Não aplicável & Não aplicável \\
\hline ITAMBE DO MATO DENTRO & 2.281 & Não aplicável & Não & Não aplicável & Não \\
\hline ITAMOGI & 10.572 & Não aplicável & Sim & Sim & Não aplicável \\
\hline ITAMONTE & 14.855 & Não aplicável & Não & Não aplicável & Não \\
\hline ITANHANDU & 14.902 & Não aplicável & Não & Não aplicável & Não aplicável \\
\hline ITANHOMI & 12.280 & Não aplicável & Não & Não aplicável & Sim \\
\hline ITAOBIM & 21.569 & Não aplicável & Não & Não aplicável & Não \\
\hline ITAPAGIPE & 14.501 & Não aplicável & Sim & Sim & $\operatorname{Sim}$ \\
\hline ITAPECERICA & 22.054 & Não aplicável & Não & Não aplicável & Sim \\
\hline ITAPEVA & 9.236 & Não aplicável & Não & Não aplicável & Não aplicável \\
\hline ITATIAIUCU & 10.563 & Não aplicável & Não & Não aplicável & Não \\
\hline ITAU DE MINAS & 15.694 & Sim & Sim & Sim & Não aplicável \\
\hline
\end{tabular}

Fonte: MMA (2016)

Observa-se que além da falta de publicidade, o PMGIRS declarado ao Ministério do Meio Ambiente, também não contempla outra exigência da PNRS: a realização de programas de educação ambiental que promovam a não geração, a redução, a reutilização e a reciclagem de resíduos sólidos, conforme previsto no inciso X, do art. 19, da PNRS (Brasil, 2010).

Em outras palavras, o município atende formalmente a exigência da PNRS de possuir um PMGIRS e tem acesso a recursos federais e estaduais destinados à gestão dos RSU, porém, deixa de atender materialmente a uma exigência crucial para o sucesso das suas próprias políticas locais de RSU: a previsão de programas de educação ambiental junto à população para que as normas que regulamentam o sistema de coleta seletiva domiciliar, de logística reversa de medicamentos vencidos, de descarte ambientalmente correto de óleo vegetal e substituição de sacolas plásticas por sacolas ecológicas fossem popularmente aceitas pela comunidade, por exemplo.

Essas constatações chamam atenção para a necessidade de criação de políticas municipais de RSU articuladas com as intencionalidades da política nacional de resíduos sólidos. No caso do Município de Itajubá, seria necessário um decreto instituindo oficialmente um PMGIRS de acordo com as exigências previstas na política nacional, principalmente, no que se refere à transparência, publicidade, participação da sociedade civil durante o processo de elaboração e implementação do plano. Além, disso tudo, a previsão de programas de educação ambiental vinculados ao PMGIRS é fundamental para ampliar as possibilidades das escolas e universidades públicas e privadas poderem contribuir para o 
processo de desenvolvimento local sustentável.

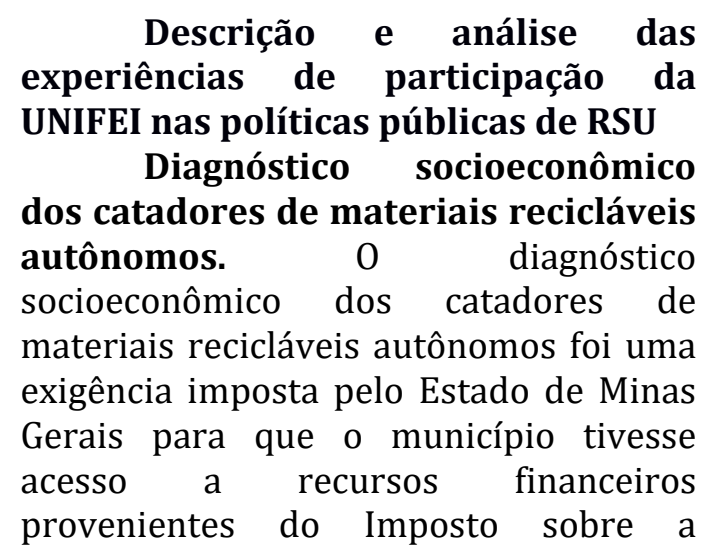

Circulação de Mercadorias e Serviços (ICMS) (ICMS Ecológico, 2016) vinculados às políticas públicas de RSU.

Para descrever essa experiência realizou-se observação participante durante sete eventos: três reuniões do Comitê Gestor de Coleta Seletiva Municipal, uma visita técnica às associações de catadores de materiais recicláveis ACIMAR e ACARI (Figuras $1 \mathrm{e}$ 2), uma participação durante a aula de mobilização dos alunos da UNIFEI sobre como aplicar os questionários socioeconômicos e dois dias de aplicação dos questionários.

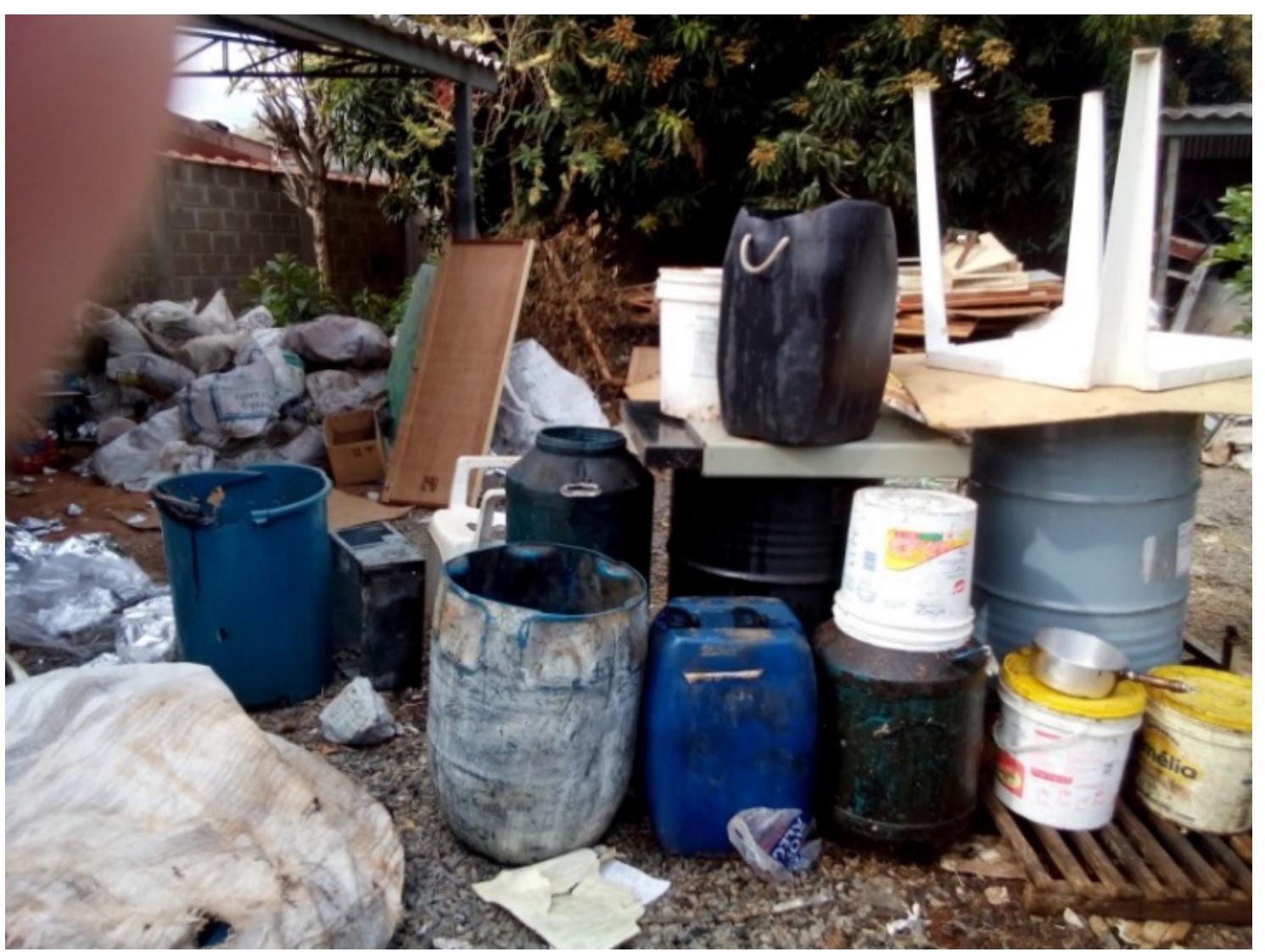

Figura 1. Armazenamento de resíduos de óleo. 


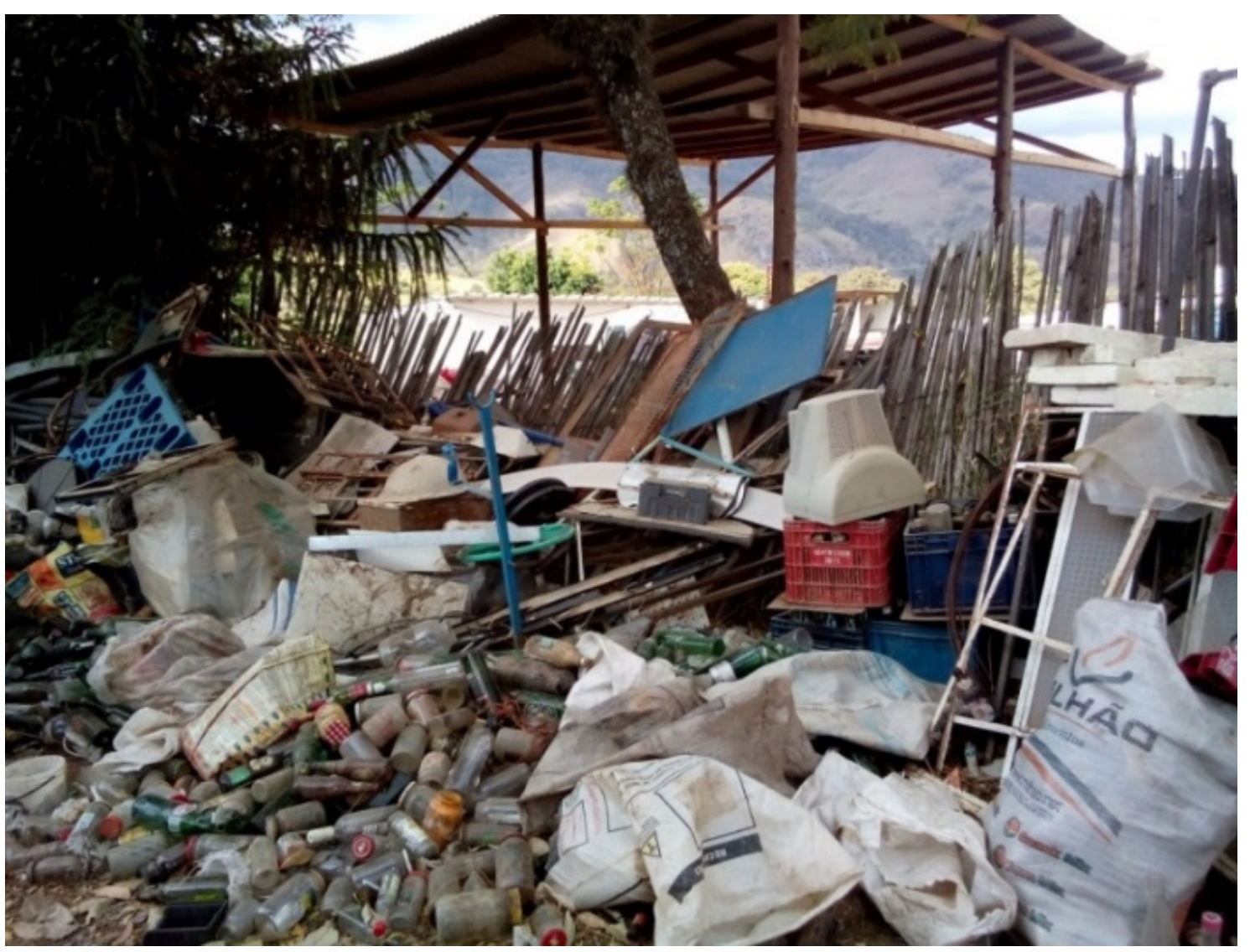

Figura 2. Armazenamento de garrafas.

Após a observação participante elaborou-se a matriz qualitativa de impacto das ações (Tabela 3). Esta matriz compara os resultados da contribuição dessa experiência para o processo de desenvolvimento local sustentável.

Da análise dos resultados dos impactos da ação nas dimensões do desenvolvimento local sustentável verificou-se que:

a) quanto ao impacto econômico: 0 diagnóstico socioeconômico não possuía uma proposta efetiva de ações a serem implementadas a partir dos dados recolhidos em parceria com a UNIFEI. Portanto a contribuição nesta dimensão após a conclusão da experiência permaneceu neutra;

b) quanto ao impacto social: havia uma expectativa de que a UNIFEI contribuiria para o impacto social que seria alcançado em decorrência da inclusão dos catadores que fossem identificados em programas sociais e de transferência de renda do governo federal pela assistência social municipal. No entanto, não foi realizada nenhuma ação nesse sentido. Por isso, a contribuição social resultou em neutra;

c) quanto ao impacto ambiental: o diagnóstico socioeconômico não possuía uma proposta efetiva de ações a serem implementadas a partir dos dados recolhidos em parceria com a UNIFEI. Portanto a contribuição nesta dimensão após a conclusão da experiência permaneceu neutra;

d) quanto ao impacto educacional: havia a expectativa de que o impacto educacional positivo seria alcançado por meio da sensibilização e da formação de uma consciência cidadã nos alunos despertando neles o interesse em desenvolver projetos 
de pesquisa vinculados às problemáticas socioambientais dos catadores de materiais recicláveis em Itajubá. Mas, o diagnóstico aconteceu somente em dois dias e não houve prosseguimento em decorrência da falta de recursos para o transporte dos alunos. Por isso, a contribuição nesta dimensão educacional para o processo de desenvolvimento local sustentável inicialmente era positiva, mas após a conclusão da experiência resultou em neutra.

Tabela 3. Matriz comparativa dos resultados da experiência de participação da UNIFEI no diagnóstico socioeconômico dos catadores de materiais recicláveis.

\begin{tabular}{|c|c|c|c|c|}
\hline \multirow{2}{*}{ EXPERIÊNCIA } & \multicolumn{4}{|c|}{ IMPACTO ESPERADO DAS AÇÕES } \\
\hline & Econômica & Social & Ambiental & Educacional \\
\hline \multirow[t]{3}{*}{$\begin{array}{l}\text { Diagnóstico } \\
\text { socioeconômico } \\
\text { dos catadores } \\
\text { de materiais } \\
\text { recicláveis } \\
\text { autônomos. }\end{array}$} & $\begin{array}{l}\text { Neutro } \\
\text { Não há previsão } \\
\text { der impacto } \\
\text { econômico com } \\
\text { esta ação. }\end{array}$ & \begin{tabular}{l}
\multicolumn{3}{c}{ Positivo } \\
Incluir os catadores \\
em programas \\
sociais e de \\
transferência de \\
renda do governo \\
federal.
\end{tabular} & \begin{tabular}{l}
\multicolumn{1}{c}{ Neutro } \\
Não há previsão de \\
impacto ambiental \\
com esta ação.
\end{tabular} & $\begin{array}{l}\text { Positivo } \\
\text { 1. Prática de } \\
\text { pesquisa de campo; } \\
\text { 2. Reconhecimento } \\
\text { da função ambiental } \\
\text { dos catadores; } \\
\text { 3. Aprendizado sobre } \\
\text { a exclusão } \\
\text { sociopolítica dos } \\
\text { catadores. }\end{array}$ \\
\hline & \multicolumn{4}{|c|}{ IMPACTO DAS AÇÕES } \\
\hline & Neutro & \begin{tabular}{lr}
\multicolumn{3}{c}{ Neutro } \\
0 diagnóstico & não \\
gerou & uma \\
proposta de ações a \\
serem \\
implementadas & a \\
partir dos & dados \\
recolhidos & em \\
parceria com & a \\
UNIFEI. &
\end{tabular} & Neutro & \begin{tabular}{|lr}
\multicolumn{2}{|c}{ Neutro } \\
Devido à ausência da \\
base instrumental da \\
participação, r as \\
dificuldades \\
logística e segurança \\
dos alunos houve a \\
desistência r da \\
participação dos \\
agentes acadêmicos \\
envolvidos.
\end{tabular} \\
\hline
\end{tabular}

A partir do referencial teórico da pesquisa é possível analisar que esta experiência de participação da UNIFEI no diagnóstico socioeconômico dos catadores autônomos de materiais recicláveis no Município de Itajubá constituía-se em uma forma da universidade participar da política pública local de RSU e contribuir com as dimensões social e educacional do desenvolvimento. Porém, esta experiência foi caracterizada pela ausência da base instrumental da participação (convênio ou contrato para fomento das atividades) e isso colaborou para que as dificuldades de logística, transporte e segurança dos agentes envolvidos resultasse na desmotivação e desistência da experiência por parte da maioria dos alunos e professores envolvidos.

Assim, apesar de atingir parte dos objetivos educacionais para a formação acadêmica dos envolvidos, apenas a base afetiva da experiência de participação não foi suficiente atingir nenhum dos impactos esperados da experiência nas dimensões social e educacional do processo de desenvolvimento local sustentável. 
Projeto "Vitória Consciente". Trata-se de um projeto de pesquisa desenvolvido por alunos do Instituto de Recursos Naturais da UNIFEI que tem como objetivo sensibilizar a comunidade do Condomínio Residencial Vitória (Figura 3) quanto à importância da separação, redução, reutilização e reciclagem do lixo, bem como, construir um abrigo para instituir a coleta seletiva. o Condomínio Residencial Vitória possui 300 apartamentos de $42 \mathrm{~m}^{2}$ divididos em 17 blocos, e, atualmente, possui cerca de 1.200 moradores. A obra foi construída pelo Programa Minha Casa Minha Vida, em 2013, dentro de uma área de $14.669,95 \mathrm{~m}^{2}$ que foi doada pela prefeitura.

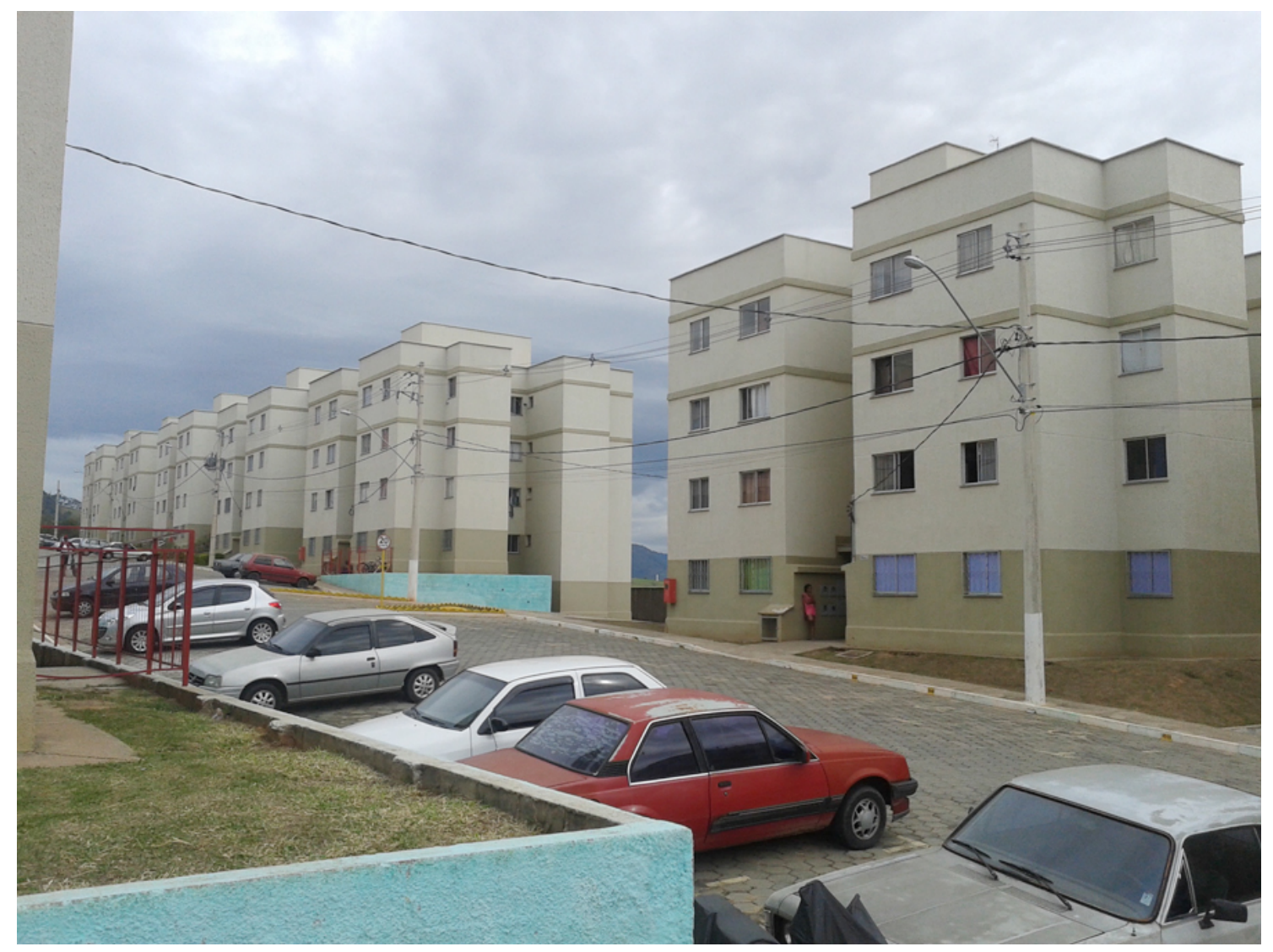

Figura 3. Residencial Vitória.

Para descrever essa experiência foi realizada observação participante durante quatro eventos: uma palestra sobre coleta seletiva de lixo, duas oficinas de artesanato com materiais recicláveis e um dia de exposição e venda dos artesanatos produzidos na Feira Agroecológica e Cultural de Itajubá (FACI) (Itajubá, 2016).
Após a observação participante elaborou-se a matriz qualitativa de impacto das ações (Tabela 4). Esta matriz compara os resultados da contribuição dessa experiência para o processo de desenvolvimento local sustentável. 
Tabela 4. Matriz comparativa dos resultados da experiência no Projeto Vitória Consciente.

\begin{tabular}{|c|c|c|c|c|}
\hline \multirow{2}{*}{ EXPERIÊNCIA } & \multicolumn{4}{|c|}{ IMPACTO ESPERADO DAS AÇÕES } \\
\hline & Econômica & Social & Ambiental & Educacional \\
\hline \multirow[t]{3}{*}{$\begin{array}{l}\text { Projeto "Vitória } \\
\text { Consciente" }\end{array}$} & \begin{tabular}{l}
\multicolumn{1}{c}{ Positivo } \\
1. Vender o \\
artesanato na feira \\
e gerar renda para \\
moradores; \\
2. Vender as \\
hortaliças da horta \\
comunitária e \\
reverter o lucro \\
para melhorias no \\
residencial.
\end{tabular} & $\begin{array}{l}\quad \text { Positivo } \\
\text { Promover } \\
\text { integração entre } \\
\text { os moradores } \\
\text { durante as } \\
\text { oficinas de } \\
\text { artesanato (lazer } \\
\text { para uns, } \\
\text { aprendizado } \\
\text { profissional para } \\
\text { outros). }\end{array}$ & $\begin{array}{l}\quad \text { Positivo } \\
\text { 1. Efetivar o sistema } \\
\text { de coleta seletiva; } \\
\text { 2.Reutilizar materiais } \\
\text { recicláveis para fazer } \\
\text { artesanato; } \\
\text { 3. Aprender a fazer } \\
\text { compostagem com } \\
\text { resíduos orgânicos. }\end{array}$ & $\begin{array}{l}\quad \text { Positivo } \\
\text { Promover o } \\
\text { retorno social do } \\
\text { investimento } \\
\text { público na UNIFEI } \\
\text { ao divulgar } \\
\text { conhecimentos } \\
\text { interdisciplinares } \\
\text { sobre RSU na } \\
\text { comunidade de } \\
\text { baixa renda. }\end{array}$ \\
\hline & \multicolumn{4}{|c|}{ IMPACTO DAS AÇÕES } \\
\hline & $\begin{array}{l}\quad \text { Positivo } \\
\text { 1. O artesanato } \\
\text { produzido foi } \\
\text { vendido na feira; } \\
\text { 2. Os moradores } \\
\text { estão vendendo as } \\
\text { hortaliças, frutas e } \\
\text { legumes da horta } \\
\text { comunitária para } \\
\text { reverter o lucro em } \\
\text { melhorias no } \\
\text { condomínio. }\end{array}$ & \begin{tabular}{l}
\multicolumn{1}{c}{ Positivo } \\
A integração \\
promovida entre \\
os moradores \\
durante as \\
oficinas reuniu \\
um grupo de \\
pessoas que \\
continuam \\
fazendo \\
artesanato e \\
outro grupo de \\
pessoas que \\
continuam a \\
cuidar da horta \\
orgânica.
\end{tabular} & $\begin{array}{l}\quad \text { Positivo } \\
\text { 1. Efetivação do } \\
\text { sistema de coleta } \\
\text { seletiva; } \\
\text { 2. Reutilização de } \\
\text { materiais recicláveis } \\
\text { para fazer artesanato; } \\
\text { 3. Está sendo feito } \\
\text { adubo orgânico para } \\
\text { a horta comunitária } \\
\text { por meio da } \\
\text { compostagem }\end{array}$ & \begin{tabular}{l}
\multicolumn{1}{c}{ Positivo } \\
O projeto foi \\
concluído, mas a \\
próxima turma \\
dará andamento. \\
Dessa forma, está \\
sendo concretizado \\
o retorno social do \\
investimento \\
público na \\
universidade ao \\
replicar os \\
conhecimentos \\
sobre RSU na \\
comunidade local.
\end{tabular} \\
\hline
\end{tabular}

Da análise dos resultados dos impactos nas dimensões do desenvolvimento local sustentável verificou-se que:

a) quanto ao impacto econômico: parte do artesanato produzido pelos moradores a partir dos materiais recicláveis foi vendido na FACI e outra parte (a dos brinquedos artesanais) foi destinada para as crianças que moram no condomínio. Os moradores continuaram cuidando da horta orgânica que foi construída na área comum do condomínio, sendo o valor arrecadado revertido para melhorias dos jardins do condomínio. Isso confirma o resultado positivo do impacto da experiência na dimensão econômica do desenvolvimento local sustentável; b) quanto ao impacto social: verificou-se a confirmação do resultado positivo do impacto da experiência na dimensão social em decorrência da integração promovida entre os moradores durante as oficinas, que após o término das atividades do projeto, continuam a se reunir para fazer artesanato, enquanto outro grupo continua cuidando da horta orgânica;

c) quanto ao impacto ambiental: verificou-se a confirmação do resultado positivo do impacto da experiência na dimensão ambiental em decorrência da efetivação do sistema de coleta seletiva dentro do condomínio evitando que os resíduos recicláveis sejam indevidamente destinados ao aterro sanitário, assim como os resíduos 
orgânicos que estão sendo reutilizados na composteira da horta orgânica;

d) quanto ao impacto educacional: verificou-se que o projeto foi concluído com satisfação por todos os alunos envolvidos. Uma aluna é moradora do condomínio e continua alimentando a página do projeto no facebook com videoaulas sobre artesanatos e reciclagem, mas a próxima turma da disciplina realizará novos projetos de pesquisa no condomínio. Dessa forma, está sendo concretizado o retorno social do investimento público na universidade ao replicar os conhecimentos sobre RSU na comunidade local, especificamente, em um condomínio residencial formado por famílias de baixa renda e distante do centro urbano da cidade.

A partir da fundamentação teórica da pesquisa também é possível analisar que essa experiência de participação da UNIFEI na política de RSU estava caracterizada pela ausência de uma base instrumental da participação na política pública (convênio ou contrato para fomento das atividades de extensão), mas, nesta situação, isso não se constituiu em um obstáculo ou dificuldade para a realização dos trabalhos.

Além de atingir aos objetivos educacionais para a formação acadêmica dos alunos envolvidos, a base afetiva da experiência de participação da UNIFEI na política pública de RSU foi essencial para atingimento dos resultados esperados da ação e para a sensibilização dos moradores. Apenas cinco alunos foram capazes de se organizar e mobilizar os moradores para que as oficinas de artesanato, de compostagem e as palestras sobre coleta seletiva ocorressem dentro do planejado.

Todas as contribuições para as dimensões do processo de desenvolvimento local sustentável foram positivas na experiência de participação da UNIFEI na política pública de RSU por meio do projeto Vitória Consciente e os próprios moradores aguardam novos trabalhos e projetos da UNIFEI que tragam melhorias para a qualidade de vida deles, para o meio ambiente da região ou simplesmente para terem algo novo para aprender e se relacionarem.

Por fim, constatou-se que o projeto Vitória Consciente não foi registrado na Pró-Reitoria de Extensão (PROEX) como uma atividade de extensão e, também, não foi divulgado pela página oficial da UNIFEI, o que poderia contribuir para a democratização da informação ambiental e o fortalecimento da imagem da universidade como um agente promotor do processo de desenvolvimento local sustentável.

\section{Projeto de extensão "Itajubá de} Olho no Óleo". O projeto de extensão "Itajubá de Olho no Óleo" foi uma iniciativa desta pesquisa para atender ao disposto na Lei Municipal no 2.940/2012, que dispõe sobre medida de reaproveitamento de óleo vegetal (cozinha) e seus resíduos. 0 objetivo foi a criação do primeiro ecoponto para o descarte adequado de óleo de cozinha usado de Itajubá (Figuras 4, 5 e 6). 


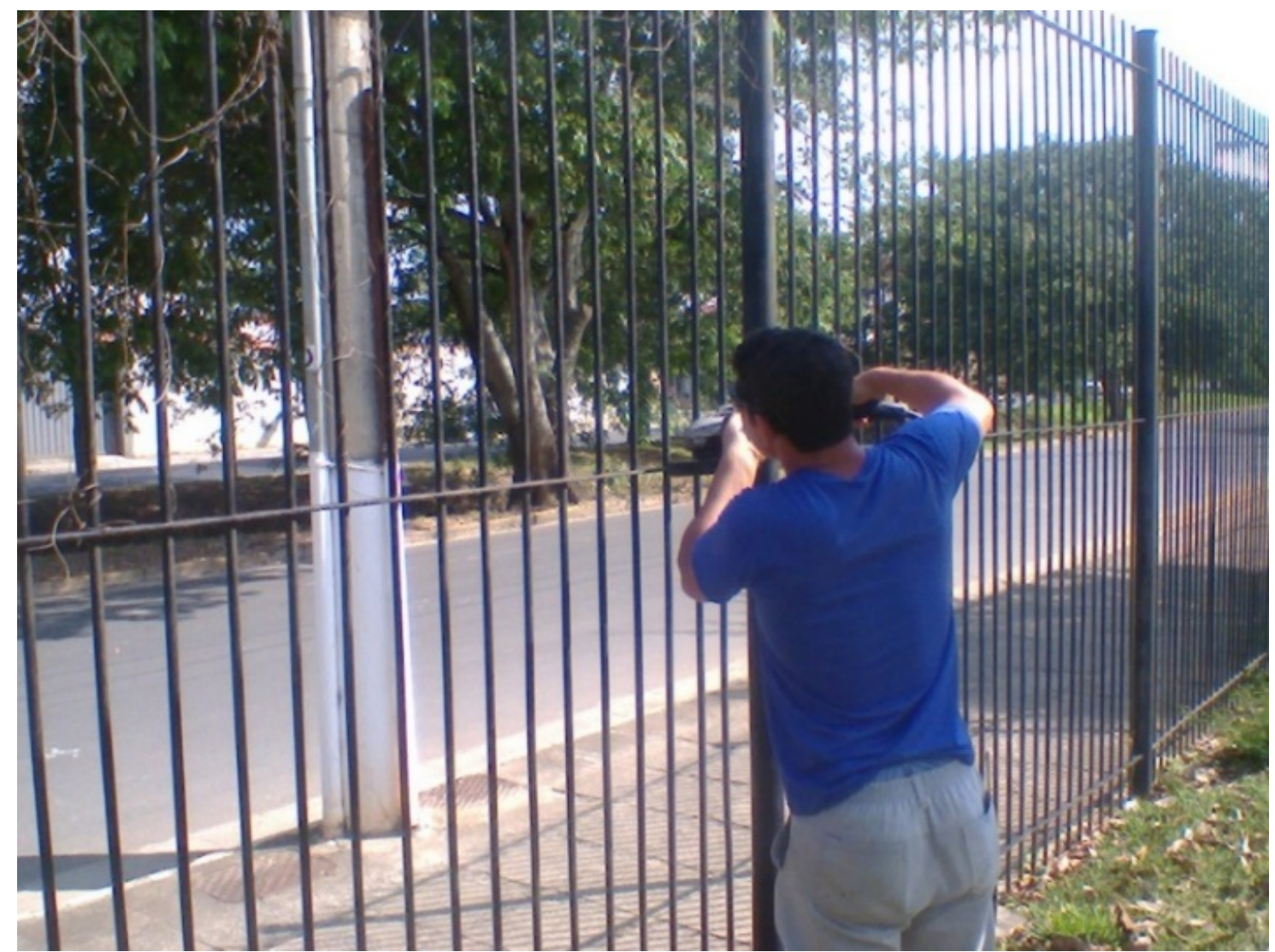

Figura 5. Momento simbólico "abertura dos muros da universidade" para a sociedade.

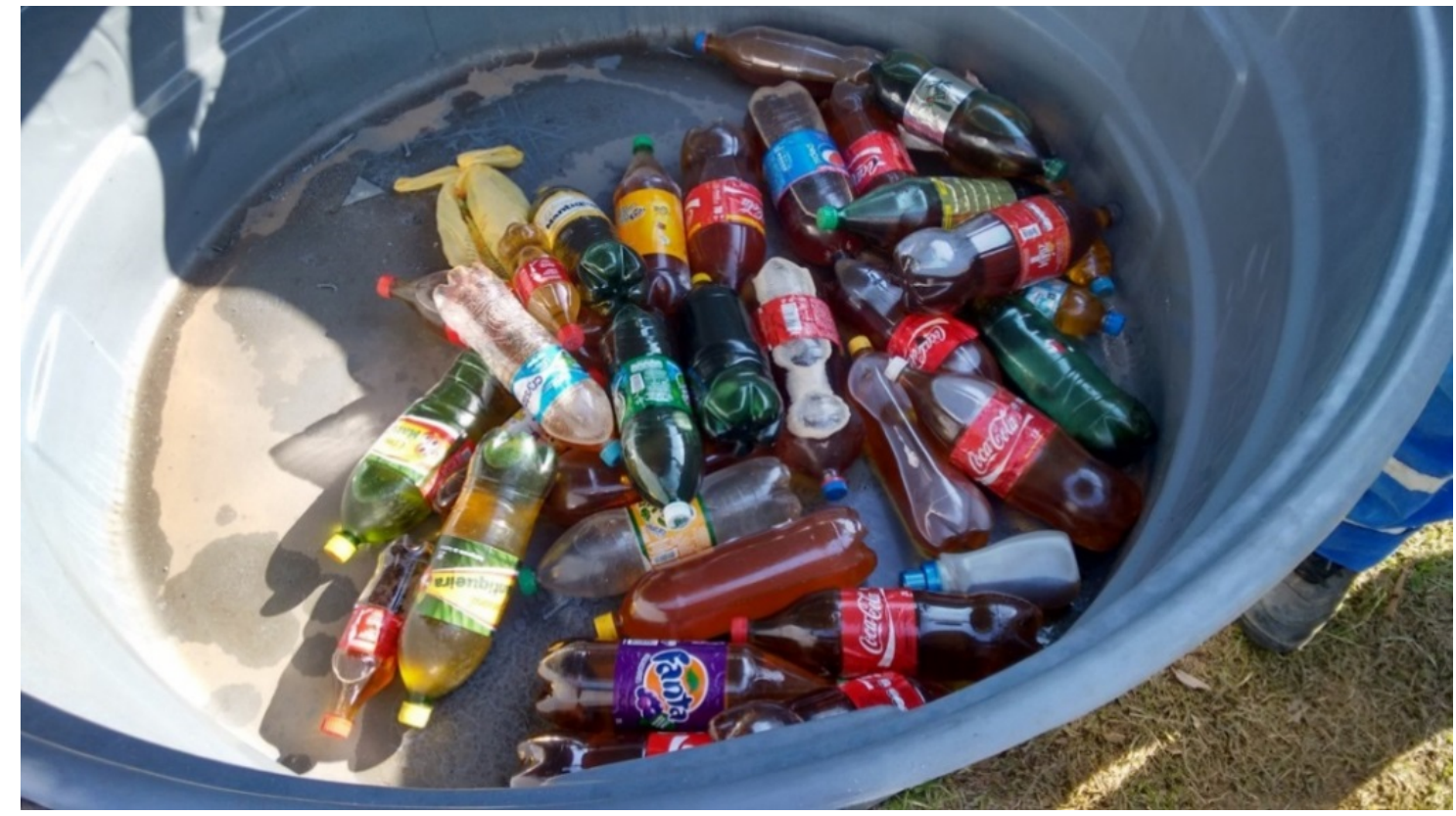

Figura 6. Foram recolhidos 64 litros de óleo vegetal no primeiro mês. 


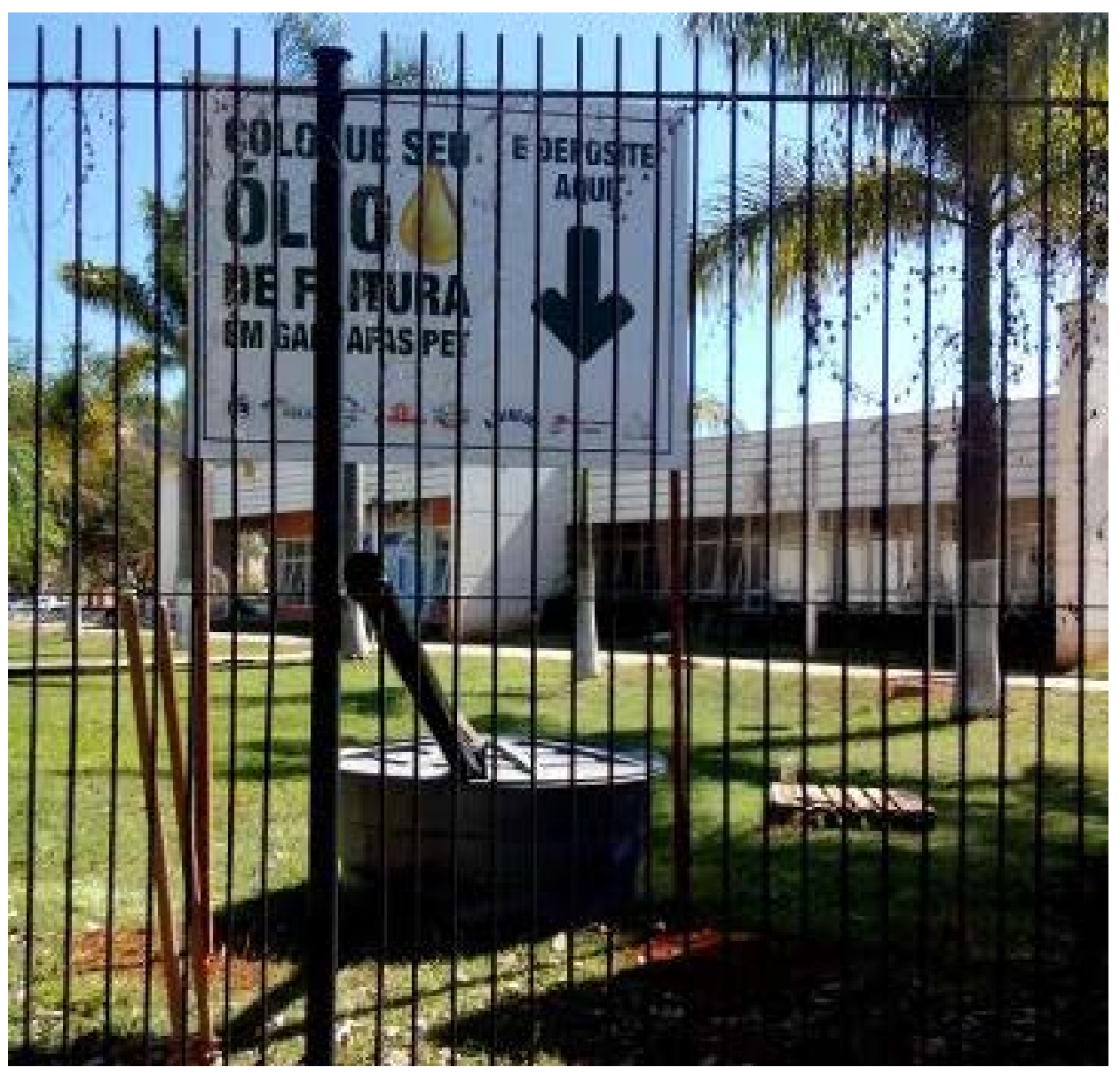

Figura 7. O Ecoponto de coleta de óleo.

A Tabela 5 calcula a recolhido no ecoponto instalado quantidade de óleo que foi na UNIFEI.

Tabela 5. Quantidade óleo de fritura.

\begin{tabular}{c|c|c|c}
\hline Data da coleta & Litros & Valor/Litro & Total (R\$) \\
\hline $30 / 09 / 2015$ & 64 & & 48,00 \\
\hline $15 / 10 / 2015$ & 190 & & 142,50 \\
\hline $16 / 11 / 2015$ & 108 & & 81,00 \\
\hline $28 / 12 / 2015$ & 161 & \multirow{2}{*}{$\$ 0,75$} & 120,75 \\
\hline $20 / 01 / 2016$ & 145 & & 108,75 \\
\hline $28 / 02 / 2016$ & 157 & & 117,38 \\
\hline $17 / 03 / 2016$ & 190 & & 142,50 \\
\hline $29 / 03 / 2016$ & 112 & & 84,00 \\
\hline $04 / 05 / 2016$ & 110 & & 148,50 \\
\hline $20 / 06 / 2016$ & 198 & & $\mathbf{1 . 0 7 5 , 8 8}$ \\
\hline Tonn & $\mathbf{1 . 4 3 5}$ & & \\
\hline
\end{tabular}


Após a observação participante elaborou-se a matriz qualitativa de impacto das ações (Tabela 6). Esta matriz compara os resultados da contribuição dessa experiência para o processo de desenvolvimento local sustentável.

Tabela 6. Matriz comparativa dos resultados do Projeto de Extensão Itajubá de Olho no Óleo.

\begin{tabular}{|c|c|c|c|c|}
\hline \multirow{2}{*}{ EXPERIÊNCIA } & \multicolumn{4}{|c|}{ IMPACTO ESPERADO } \\
\hline & Econômica & Social & Ambiental & Educacional \\
\hline \multirow[t]{3}{*}{$\begin{array}{l}\text { Projeto de } \\
\text { Extensão } \\
\text { Itajubá de } \\
\text { no Olho } \\
\end{array}$} & \begin{tabular}{l}
\multicolumn{1}{c}{ Positivo } \\
Agregar valor ao \\
óleo vegetal \\
descartado ao \\
transformá-lo em \\
sabão ou ser \\
vendido para \\
indústria de \\
reciclagem. \\
\end{tabular} & \begin{tabular}{l}
\multicolumn{1}{c}{ Positivo } \\
Doar o óleo vegetal \\
recolhido para a \\
ACIMAR fortalecendo \\
a associação de \\
catadores.
\end{tabular} & \begin{tabular}{l}
\multicolumn{1}{c}{ Positivo } \\
Evitar que o óleo de \\
fritura seja lançado nas \\
pias, ralos e solos da \\
cidade, evitando a \\
poluição dos recursos \\
naturais.
\end{tabular} & \begin{tabular}{|l|}
\multicolumn{1}{|c|}{ Positivo } \\
Promover a \\
educação \\
ambiental sobre a \\
correta \\
destinação do \\
óleo de fritura. \\
(Lei municipal no \\
2.940/12). \\
\end{tabular} \\
\hline & \multicolumn{4}{|c|}{ IMPACTO REALIZADO } \\
\hline & \begin{tabular}{l}
\multicolumn{1}{c}{ Positivo } \\
Foi agregado valor \\
ao óleo vegetal \\
descartado ao ser \\
vendido para \\
indústria de \\
reciclagem por \\
$\mathrm{R} \$ 0,75$ o litro e foi \\
arrecadado o total \\
de $\mathrm{R} \$ 1.075,88$, \\
para a ACIMAR.
\end{tabular} & \begin{tabular}{l}
\multicolumn{1}{c}{ Positivo } \\
A população tem \\
aproveitado a \\
caminhada matinal \\
para depositar o óleo \\
de fritura no \\
ecoponto da UNIFEI, \\
alunos e servidores \\
também utilizam o \\
ecoponto.
\end{tabular} & \begin{tabular}{|l}
\multicolumn{1}{c|}{ Positivo } \\
Foi evitado que 1.435 \\
litros de óleo de fritura \\
fossem lançados nas \\
pias, ralos e solos da \\
cidade, evitando a \\
poluição dos recursos \\
naturais.
\end{tabular} & \begin{tabular}{|l}
\multicolumn{1}{c|}{ Positivo } \\
Foi promovida a \\
educação \\
ambiental ao \\
sensibilizar a \\
sociedade sobre a \\
correta \\
destinação do \\
RSU e outros \\
projetos estão \\
sendo realizados \\
a partir do \\
ecoponto.
\end{tabular} \\
\hline
\end{tabular}

\author{
Da análise dos resultados dos \\ impactos nas dimensões do \\ desenvolvimento local sustentável \\ verificou-se que:
}

a) quanto ao impacto econômico: confirmou-se o resultado positivo do impacto da experiência na dimensão econômica em decorrência do valor agregado ao óleo vegetal descartado pelas pessoas no ecoponto instalado junto aos muros da UNIFEI. A ACIMAR vendeu o litro de óleo para a indústria de reciclagem por $\mathrm{R} \$ 0,75$ (setenta e cinco centavos). Em nove meses de funcionamento o ecoponto contribuiu para gerar a quantia de $\mathrm{R} \$ 1.075,88$ (mil, setenta e cinco reais e oitenta e oito centavos) que foi convertida em renda para os quinze catadores de materiais recicláveis que são associados à ACIMAR;

b) quanto ao impacto social: confirmou-se o resultado positivo do impacto da experiência na dimensão social em decorrência da popularização do ecoponto do projeto "Itajubá de Olho no Óleo" junto à sociedade. Apesar de a Lei Municipal no 2.940/2012 que dispõe sobre medida de reaproveitamento de óleo vegetal (cozinha) estar em vigor há quatro anos, a população não tinha um local apropriado e de fácil acesso para se desfazerem do resíduo doméstico. Além disso, a ACIMAR, por meio da INTECOOP, está investindo na divulgação do ecoponto nas residências e nas redes 
sociais para que a população aproveite a sua caminhada matinal em torno do campus da UNIFEI para depositar o óleo no ecoponto;

c) quanto ao impacto ambiental: confirmou-se o resultado positivo do impacto da experiência na dimensão ambiental em decorrência do aumento significativo da quantidade do resíduo que tem sido descartado no ecoponto após sua instalação junto aos muros da UNIFEI. Enquanto o ecoponto era um tambor dentro do campus a sua visibilidade e acessibilidade era restrita às pessoas que circulavam nos arredores do restaurante acadêmico. Após a instalação do ecoponto junto ao muro, qualquer pessoa (vinculada ou não à universidade) pode depositar a garrafa contendo o resíduo pelo cano, sem a necessidade de entrar no campus. Se uma gota de óleo pode poluir até 1.000 (mil) litros de água, ao arrecadar 1.435 litros dentro de dez meses de funcionamento, 0 ecoponto evitou que 1.435.000 (um milhão, quatrocentos e trinta e cinco mil) litros de recursos hídricos fossem contaminados pelo desfazimento incorreto do resíduo;

d) quanto ao impacto educacional: verificou-se a confirmação do resultado positivo do impacto da experiência na dimensão educacional em decorrência do registro do trabalho como um projeto de extensão. Além disso, outras pesquisas estão sendo realizadas por alunos da UNIFEI a partir ecoponto que se tornou permanente e recebe manutenção da própria Prefeitura do Campus. Dessa maneira, está sendo promovida a educação ambiental ao transmitir para todos a mensagem sobre a correta destinação do RSU.

A partir da fundamentação teórica desta pesquisa é possível analisar que essa experiência de participação da UNIFEI na política pública de RSU estava caracterizada pela ausência de uma base instrumental da participação (convênio ou contrato para fomento das atividades de extensão, tais como construção e manutenção do ecoponto), mas, diferentemente da primeira experiência analisada, nesta situação, isso não se constituiu em um obstáculo ou dificuldade para a realização dos trabalhos.

Além de atingir aos objetivos educacionais para a formação acadêmica dos alunos e servidores envolvidos, a base afetiva da experiência foi suficiente para atingimento dos resultados esperados da ação e para a sensibilização dos gestores da UNIFEI que doaram os materiais necessários para a construção e manutenção do ecoponto (cano de PVC, tinta, caixa d'água de 1000 litros, placa de divulgação, estacas de madeira, mãode-obra para instalação, elaboração de arte e divulgação nos canais oficiais da UNIFEI). Tal situação desconstrói a hipótese preliminar da pesquisa de que a universidade somente participaria das políticas públicas de RSU para atender a demandas de editais e convênios para a realização de pesquisas de cunho tecnológico sem se envolver afetivamente com a sociedade, para juntos, enfrentarem as problemáticas que envolvem os RSU.

Da análise dos resultados desta experiência também é possível analisar que a cooperação entre as universidades e o poder local representa um avanço em prol do desenvolvimento sustentável e pode ser um fator determinante para 0 sucesso das políticas de desenvolvimento urbanas, como é o caso da Lei Municipal no 2.940/2012 que dispõe sobre medida de reaproveitamento de óleo vegetal (cozinha), em vigor há quatro anos no município, porém, sem efetividade junto à população devido à falta de locais acessíveis para o desfazimento do resíduo.

Audiência Pública para elaboração dos Planos de Saneamento Básico. Trata-se de uma experiência de participação da UNIFEI na política pública de RSU em que a universidade, por meio do seu corpo docente composto por seis professores foi responsável por 
elaborar e executar o Plano de Mobilização Social (Itajubá, 2015) para a elaboração e revisão dos Planos Municipais e Regional de Saneamento Básico que abrangerá os seis municípios que compõem o CIMASAS: Itajubá, São José do Alegre, Piranguinho, Piranguçu, Delfim Moreira e Wenceslau Braz.

0 objetivo geral do Plano de Mobilização Social elaborado pela UNIFEI foi estimular a participação da sociedade durante as etapas do processo de elaboração e revisão dos Planos Municipais de Saneamento, de forma a sensibilizar a população para a responsabilidade coletiva de todos pela preservação e conservação dos recursos naturais.

Após a observação participante elaborou-se a matriz qualitativa de impacto das ações (Tabela 7). Esta matriz compara os resultados da contribuição dessa experiência para o processo de desenvolvimento local sustentável.

Tabela 7. Matriz comparativa dos resultados da experiência na Audiência Pública.

\begin{tabular}{|c|c|c|c|c|}
\hline \multirow{2}{*}{ EXPERIÊNCIA } & \multicolumn{4}{|c|}{ IMPACTO ESPERADO } \\
\hline & Econômica & Social & Ambiental & Educacional \\
\hline \multirow[t]{3}{*}{$\begin{array}{l}\text { Audiência } \\
\text { pública para } \\
\text { elaboração } \\
\text { dos Planos } \\
\text { Municipais e } \\
\text { Regional de } \\
\text { Saneamento } \\
\text { Básico }\end{array}$} & \begin{tabular}{l}
\multicolumn{1}{c}{ Neutro } \\
A participação da \\
UNIFE, por si só, \\
não possui o \\
potencial de gerar \\
impacto de cunho \\
econômico.
\end{tabular} & \begin{tabular}{l}
\multicolumn{1}{c}{ Positivo } \\
Contribuir para a \\
transparência e \\
participação \\
social durante a \\
elaboração dos \\
Planos de \\
Saneamento.
\end{tabular} & \begin{tabular}{l}
\multicolumn{1}{c}{ Neutro } \\
A participação da \\
UNIFEI, por si só, \\
não possui o \\
potencial de gerar \\
algum impacto de \\
cunho ambiental.
\end{tabular} & \begin{tabular}{l}
\multicolumn{1}{c}{ Positivo } \\
Sensibilizar a \\
comunidade sobre a \\
importância de todos \\
participarem das \\
políticas de RSU do \\
lugar onde vivem.
\end{tabular} \\
\hline & \multicolumn{4}{|c|}{ IMPACTO REALIZADO } \\
\hline & \begin{tabular}{l}
\multicolumn{1}{c}{ Neutro } \\
A participação da \\
UNIFEI, por si só, \\
não gerou \\
impacto de cunho \\
econômico.
\end{tabular} & \begin{tabular}{l}
\multicolumn{1}{c}{ Positivo } \\
Contribuiu para a \\
transparência e \\
participação \\
social durante a \\
audiência pública.
\end{tabular} & \begin{tabular}{l}
\multicolumn{1}{c}{ Neutro } \\
A participação da \\
UNIFEI, por si só, \\
não possuiu o \\
potencial de gerar \\
algum impacto \\
imediato de cunho \\
ambiental.
\end{tabular} & \begin{tabular}{l}
\multicolumn{1}{c}{ Positivo } \\
Fortalecimento da \\
consciência cidadã na \\
comunidade (interna e \\
externa ao campus) \\
sobre a importância de \\
participar das políticas \\
de RSU onde vivem.
\end{tabular} \\
\hline
\end{tabular}

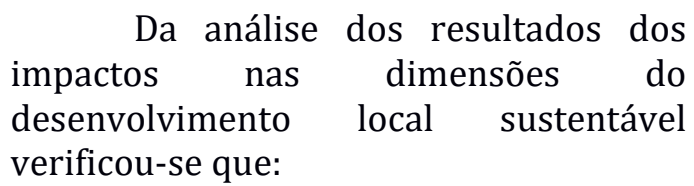

a) quanto ao impacto econômico: a participação da UNIFEI, por si só, não possui o potencial de gerar impactos de cunho econômico no processo de desenvolvimento. Portanto a contribuição nesta dimensão após a conclusão da experiência permaneceu neutra;

b) quanto ao impacto social: a participação da UNIFEI na audiência pública para elaboração dos Planos Municipais e Regional de Saneamento Básico tinha por objetivo promover a mobilização social e estimular a participação popular nas etapas do processo de elaboração dos planos de saneamento dos seis municípios que compõem o CIMASAS. Apesar do baixo índice de comparecimento, as pessoas foram participativas e questionadoras em relação às colocações dos responsáveis pela elaboração dos planos. Nesse sentido, confirmou-se o impacto positivo da contribuição desta experiência para a dimensão social 
do processo de desenvolvimento local sustentável. Porém, é importante ressaltar que a mobilização social não alcançou todas as camadas da população dos municípios envolvidos e a divulgação no campus também não foi expressiva;

c) quanto ao impacto ambiental: a participação da UNIFEI na organização da audiência pública não possui, de imediato, o potencial de gerar algum impacto de cunho ambiental. Por isso, a contribuição na dimensão ambiental após a conclusão da experiência permaneceu neutra;

d) quanto ao impacto educacional: a experiência de participação da UNIFEI como sendo a responsável por promover a mobilização social para a audiência pública contribuiu para o fortalecimento da consciência cidadã na comunidade (interna e externa ao campus) sobre a importância de todos participarem do processo de elaboração das políticas de RSU do lugar onde vivem. Ao participar de algo tão importante, a universidade cumpre o estabelecido no artigo 205 da CF/88, de incentivar a educação em colaboração com a sociedade preparando os jovens para o exercício da cidadania. Nesse sentido, confirmou-se o impacto positivo da contribuição desta experiência para a dimensão educacional do processo de desenvolvimento local sustentável.

A partir do referencial teórico da pesquisa também é possível analisar que, diferentemente das três experiências analisadas anteriormente, esta experiência de participação da UNIFEI foi caracterizada pela presença das duas bases complementares da participação nas políticas públicas que são defendidas por Bordenave (1994): a base afetiva e a base instrumental (convênio celebrado entre a UNIFEI e o CIMASAS para elaboração e execução do Plano de Mobilização Social). No entanto, assim como previu o pesquisador, a duas bases da participação que deveriam equilibrarse acabaram por entrar em conflito e a base instrumental se sobrepôs à base afetiva da participação.

Ou seja, apesar de atingir parte dos objetivos sociais e educacionais esperados, ao preocupar-se em cumprir as metas e os objetivos estipulados no instrumento "Plano de Mobilização Social" elaborado como o produto $\mathrm{n}^{-} 01$ solicitado pelo CIMASAS, a base afetiva da participação foi prejudicada. Neste caso, a participação mais afetiva da UNIFEI seria essencial para conferir maior amplitude na divulgação da audiência pública nos canais oficiais de comunicação dos municípios envolvidos (estações de rádio locais, jornais locais e TV) e dentro do próprio campus universitário.

Projetos de pesquisa e extensão relacionados aos RSU. Foi solicitado à UNIFEI cópia dos registros de projetos de extensão que abordassem a temática dos resíduos ou reciclagem. Apenas seis projetos estavam registrados e da análise desses documentos elaborou-se a Tabela 8 com a identificação dos projetos de extensão relacionados aos RSU. 
Tabela 8. Projetos de extensão registrados na UNIFEI relacionados aos RSU.

\begin{tabular}{|c|c|c|}
\hline № & ANO & PROJETO DE EXTENSÃO \\
\hline 1050 & 2013 & $\begin{array}{l}\text { Criação de uma rede de catadores de materiais recicláveis no sul de Minas } \\
\text { Gerais } \\
\text { Objetivo: fomentar a constituição de uma rede de organizações voltadas ao } \\
\text { gerenciamento de materiais recicláveis na área de abrangência do CIMASAS e } \\
\text { fortalecer a organização política, administrativa e jurídica das associações já } \\
\text { existentes e incubadas pela INTECOOP/UNIFEI. }\end{array}$ \\
\hline 1219 & 2014 & $\begin{array}{l}\text { Curso de Gestão de Resíduos Industriais - } \mathbf{1 6} \text { horas } \\
\text { Objetivo: apresentar os princípios do direito ambiental inerentes ao setor } \\
\text { industrial, o gerenciamento de resíduos com base na Lei no } 12.305 / 2010 \text { PNRS, os } \\
\text { limites permitidos para a emissão de poluentes gasosos, líquidos e sólidos, bem } \\
\text { como as penalidades previstas em caso de descumprimento da legislação. }\end{array}$ \\
\hline 1037 & 2014 & $\begin{array}{l}\text { Fortalecimento da coleta seletiva na UNIFEI } \\
\text { Objetivo: fortalecer a coleta seletiva por meio de ações de educação ambiental } \\
\text { visando colaborar com a ACIMAR. Período: } 22 / 08 / 2013 \text { a } 05 / 07 / 2014 \text {. }\end{array}$ \\
\hline 1302 & 2014 & $\begin{array}{l}\text { Educação ambiental inclusiva e implantação de coleta seletiva em uma } \\
\text { escola pública de Itajubá } \\
\text { Objetivo: utilizar as artes cênicas como proposta pedagógica de educação } \\
\text { ambiental inclusiva e, dessa forma, mobilizar a comunidade escolar para a } \\
\text { implantação de um sistema de coleta seletiva na Escola Estadual Coronel Carneiro } \\
\text { Júnior. }\end{array}$ \\
\hline 1362 & 2015 & $\begin{array}{l}\text { Curso de Gestão de Resíduos Industriais - } 16 \text { horas } \\
\text { Apresentar os princípios do direito ambiental inerentes ao setor industrial, o } \\
\text { gerenciamento de resíduos com base na Lei } \mathrm{n}^{\mathrm{0}} 12.305 / 2010 \text { PNRS, os limites } \\
\text { permitidos para a emissão de poluentes gasosos, líquidos e sólidos, bem como as } \\
\text { penalidades previstas em caso de descumprimento da legislação. }\end{array}$ \\
\hline 1498 & 2015 & $\begin{array}{l}\text { Ecoponto para coleta de óleo de fritura: Itajubá de Olho no óleo } \\
\text { Objetivo: sensibilizar as pessoas para o descarte adequado do óleo de cozinha } \\
\text { usado para que não seja indevidamente lançado na pia, nos solos ou no aterro } \\
\text { sanitário, bem como, promover a inclusão social de catadores de materiais } \\
\text { recicláveis no município de Itajubá/MG por meio da reutilização deste óleo vegetal } \\
\text { para a produção de biodiesel e sabão. }\end{array}$ \\
\hline
\end{tabular}

Também foi realizada uma busca no website oficial da UNIFEI pelas seguintes palavras-chave: coleta, resíduo, sólido, lixo e reciclagem, e, além dos projetos de extensão já mencionados no quadro 6 , identificou-se o projeto de pesquisa "GT 418: Gaseificação de RSU para a Geração de Eletricidade", financiado pela CEMIG/ANEEL. O objetivo desse projeto é construir e operar uma planta piloto de gaseificação de RSU.

Após a observação participante elaborou-se a matriz qualitativa de impacto das ações (Tabela 9). Esta matriz compara os resultados da contribuição dessa experiência para o processo de desenvolvimento local sustentável. 
Tabela 9. Matriz qualitativa comparativa do impacto da experiência de participação da UNIFEI em Projetos de pesquisa e extensão relacionados aos RSU.

\begin{tabular}{|c|c|c|c|c|}
\hline \multirow{2}{*}{ EXPERIÊNCIA } & \multicolumn{4}{|c|}{ IMPACTO ESPERADO } \\
\hline & Econômica & Social & Ambiental & Educacional \\
\hline \multirow[t]{3}{*}{$\begin{array}{l}\text { Projetos de } \\
\text { pesquisa e } \\
\text { extensão } \\
\text { relacionados } \\
\text { aos RSU }\end{array}$} & $\begin{array}{l}\quad \text { Positivo } \\
\text { Os projetos de } \\
\text { pesquisa e } \\
\text { extensão visam a } \\
\text { redução dos } \\
\text { custos } \\
\text { operacionais com } \\
\text { a gestão dos RSU } \\
\text { e a geração de } \\
\text { renda. }\end{array}$ & \begin{tabular}{|l}
\multicolumn{1}{c|}{ Positivo } \\
Os projetos de \\
pesquisa e extensão \\
abrangem as \\
problemáticas sociais \\
relacionadas aos \\
catadores de \\
materiais recicláveis.
\end{tabular} & \begin{tabular}{l}
\multicolumn{1}{c}{ Positivo } \\
Democratizar da \\
informação \\
ambiental para sua \\
aplicabilidade nos \\
problemas \\
ambientais \\
relacionados aos \\
RSU.
\end{tabular} & \begin{tabular}{l}
\multicolumn{1}{c}{ Positivo } \\
Promover o \\
retorno social do \\
investimento \\
público na \\
UNIFEI, ao \\
replicar os \\
conhecimentos \\
em RSU na \\
comunidade local.
\end{tabular} \\
\hline & \multicolumn{4}{|c|}{ IMPACTO REALIZADO } \\
\hline & \begin{tabular}{l}
\multicolumn{1}{c}{ Positivo } \\
Projetos como \\
"Itajubá de Olho \\
no Óleo" e o \\
projeto GT 418: \\
Gaseificação de \\
RSU para a \\
Geração de \\
Eletricidade, \\
atingem a \\
dimensão \\
econômica com \\
impacto local.
\end{tabular} & \begin{tabular}{|l}
\multicolumn{1}{c|}{ Positivo } \\
Projetos como \\
"Criação de uma rede \\
de catadores de \\
materiais recicláveis \\
no sul de Minas \\
Gerais" abrangem as \\
problemáticas sociais \\
relacionadas aos \\
catadores de \\
materiais recicláveis.
\end{tabular} & \begin{tabular}{|l}
\multicolumn{1}{|c}{ Positivo } \\
Projetos como \\
"Reuso de óleo: \\
transformação para \\
fins domésticos em \\
repúblicas de \\
Itajubá/MG" \\
democratizam a \\
informação \\
ambiental para sua \\
aplicabilidade nos \\
problemas \\
ambientais causados \\
pelos RSU.
\end{tabular} & \begin{tabular}{|l}
\multicolumn{1}{c}{ Positivo } \\
A UNIFEI \\
promove o \\
retorno social do \\
investimento \\
público ao \\
replicar os \\
conhecimentos \\
em RSU na \\
comunidade local \\
porém, sem \\
atentar para a \\
base instrumental \\
(registros dos \\
projetos)
\end{tabular} \\
\hline
\end{tabular}

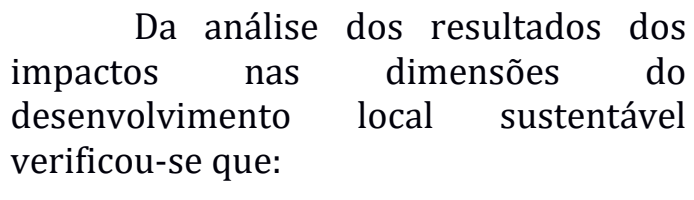

a) quanto ao impacto econômico: projetos como "Itajubá de Olho no Óleo e o projeto GT 418: Gaseificação de RSU para a Geração de Eletricidade atingem a dimensão econômica com impacto local. Isso confirma o resultado positivo do impacto da experiência de participação da UNIFEI nas políticas públicas de RSU por meio de projetos de pesquisa e extensão;

b) quanto ao impacto social: projetos de extensão como a "Criação de uma rede de catadores de materiais recicláveis" e projetos de pesquisa como "Sensibilização ambiental: dando voz aos catadores autônomos de materiais recicláveis de Itajubá-MG", são experiências de participação da UNIFEI nas políticas públicas de RSU que abrangem as problemáticas sociais relacionadas aos catadores de materiais recicláveis. Por isso, também foi confirmado o resultado positivo do impacto da experiência na dimensão social;

c) quanto ao impacto ambiental: foi confirmado o resultado positivo do impacto da experiência na dimensão ambiental em decorrência da realização de projetos de pesquisa e extensão que visem a democratização da informação ambiental junto à comunidade, $\mathrm{o}$ fortalecimento do sistema de coleta seletiva, a redução e a reutilização de resíduos como o óleo vegetal; 
d) quanto ao impacto educacional: verificou-se que a UNIFEI tem realizado projetos de pesquisa e extensão relacionados com as problemáticas locais que envolvem os RSU. Porém, como se pode analisar pelo quadro 6 , apenas seis projetos de extensão estavam registrados na PROEX. Esse fato chama a atenção para a necessidade de formalização dos projetos de extensão que são realizados pela UNIFEI junto à comunidade. 0 registro confere maior divulgação de iniciativas tão importantes e enriquece o diálogo informado entre universidade e sociedade se tornando uma via de mão dupla onde todos ganham. Em relação aos projetos de pesquisa percebe-se que a maioria tem se apoiado unicamente sobre a base afetiva da participação, mas, ainda assim, tem concretizado o retorno social do investimento público na universidade ao replicar os conhecimentos sobre RSU na comunidade local.

A partir da fundamentação teórica desta pesquisa é possível analisar que a participação da UNIFEI nas políticas públicas de RSU por meio da realização de projetos de pesquisa e extensão têm causado impactos positivos em todas as dimensões do processo de desenvolvimento local sustentável.

Analisando criticamente, não se pode deixar de observar que a maioria dos projetos que a UNIFEI tem desenvolvido em relação aos RSU são de curta duração, ao contrário de grupos de pesquisa permanentes como o GRS/UFPE. A concentração dessas ações vinculadas a um grupo permanente dedicado à pesquisa e extensão sobre as problemáticas interdisciplinares que envolvem os RSU na sociedade pode ser um importante passo para o fortalecimento dos pequenos projetos de pesquisa e extensão que têm sido empreendidos, muita das vezes, por iniciativas solitárias de alguns acadêmicos.

\section{Conclusão}

A hipótese preliminar de que a UNIFEI somente participava das políticas públicas de RSU de maneira instrumental não se confirmou, já que em quatro das cinco experiências analisadas constatouse que ao realizar projetos "fora dos muros da universidade" e sem a necessidade de recursos financeiros ou instrumentos jurídicos que ditem os limites do seu agir social, a UNIFEI tem interagido "afetivamente" com a comunidade para a troca de experiências e conhecimentos relacionados com as problemáticas locais que envolvem os RSU.

De outro modo, ao realizar experiências de participação que se apoiam unicamente sobre a base instrumental para atendimento de editais de fomento à pesquisa científica e tecnológica, a universidade também dá um passo em direção à formação cidadã dos alunos que utilizam o conhecimento adquirido em sala de aula para o desenvolvimento de soluções e serviços que atendam às complexas demandas tecnológicas que envolvem a gestão dos resíduos na sociedade.

Porém, cada tipo de experiência tem contribuído em maior ou menor grau para processo de desenvolvimento sustentável. Um fato importante é que mesmo o PMGIRS de Itajubá não tendo contemplado a realização de programas de educação ambiental junto à população, na forma como determina a PNRS, a UNIFEI tem realizado ações articuladas com o município com vistas à execução de projetos que visam a não geração, a redução, a reutilização e a reciclagem de resíduos sólidos.

0 processo decisório que culmina na elaboração de políticas relacionadas aos RSU impacta diretamente na qualidade do meio ambiente de qualquer região e as consequências, sejam elas positivas ou negativas, refletem na qualidade de vida e na saúde de toda a população. Por isso, é importante a participação de todos nas políticas de RSU, principalmente, dos atores sociais 
com conhecimento multidisciplinares acerca das problemáticas que os envolvem, tais como as universidades.

\section{Conflito de interesses}

As autoras declaram não haver conflito de interesses.

\section{Referências}

Abreu, M. F. Coleta seletiva com inclusão social: em municípios, empresas, instituições, condomínios, escolas. Belo Horizonte: CREA-MG, 2008.

Aguiar, R. A. R. Direito do meio ambiente e participação popular. 3. ed. Brasília: Edições IBAMA, 2002.

Bordenave, J. E. D. 0 que é participação. 8. ed. São Paulo: Brasiliense, 1994.

Brasil. Lei no 11.107, de 6 de abril de 2005. Dispõe sobre normas gerais de contratação de consórcios públicos e dá outras providências. Disponível em: <http://www.planalto.gov.br/ccivil_03/_ato 2004-2006/2005/lei/l11107.htm>. Acesso em: 23 set. 2017 .

Brasil. Lei no 12.305, de 2 de agosto de 2010. Institui a Política Nacional de Resíduos Sólidos; altera a Lei no 9.605, de 12 de fevereiro de 1998; e dá outras providências. Disponível em: <http://www.planalto. gov.br/ccivil_03/_ato2007-2010/2010/lei/ l12305.htm>. Acesso em: 23 set. 2017.

Brasil. Decreto no 7.404, de 23 de dezembro de 2010. Regulamenta a Lei $\mathrm{n}^{\circ} 12.305$, de 2 de agosto de 2010, que institui a Política Nacional de Resíduos Sólidos, cria o Comitê Interministerial da Política Nacional de Resíduos Sólidos e o Comitê Orientador para a Implantação dos Sistemas de Logística Reversa, e dá outras providências. Disponível em: <http://www.planalto.gov.br/ccivil_03/_ato 2007-2010/2010/decreto/d7404.htm>. Acesso em: 23 set. 2017.

Buarque, S. C. Construindo o desenvolvimento local sustentável. 4. ed. Rio de Janeiro: Garamond, 2008.

Cempre-Compromisso Empresarial para Reciclagem. Radiografando a coleta seletiva. 2016. Disponível em: <http://cempre.org.br/ ciclosoft/id/8>. Acesso em: jun. 2016.

Gattari, F. As três ecologias. Campinas: Papirus, 1990.
GRS/UFPE - Grupo de Resíduos Sólidos da Universidade Federal de Pernambuco. Apresentação. Disponível em: <http://www.grs-ufpe.com.br/ogrs/>.

Acesso em: 11 set. 2017.

GRS/UFPE - Grupo de Resíduos Sólidos da Universidade Federal de Pernambuco. Análise das diversas tecnologias de tratamento e disposição final de resíduos sólidos urbanos no Brasil, Europa, Estados Unidos e Japão. Jaboatão dos Guararapes: GRS/UFPE, 2014.

Habermas, J. Facticidad y validez: sobre el derecho y el Estado democrático de derecho em términos de teoria del discurso. Madrid: Trotta, 1998.

ICMS Ecológico. Histórico e perspectivas. 2016. Disponível em: <http://www.icms ecologico.org.br/site/index.php?option=com _content\&view=article\&id=72\&Itemid=77>. Acesso em: 23 mar. 2018.

IPEA - Instituto de Pesquisa Econômica Aplicada. Estado, instituições e democracia: república. Brasília: Ipea, 2010. Livro 9. v. $1 . \quad$ Disponível em: <http://www.ipea.gov.br/agencia/images/st ories/PDFs/livros/livros/livro09_estadoinsti tuicoes_vol1>. Acesso em: 21 mar. 2018.

Itajubá (MG). Plano de Mobilização Social elaborado por professores da UNIFEI. Disponível em: <http://www.itajuba.mg. gov.br/semma/planodesaneamentobasico/P RODUTO_1-PLANO_DE_MOBILIZACAO_

SOCIAL.pdf>. Acesso em: 12 dez. 2017.

Itajubá (MG). História, localização e infraestrutura. Disponível em: <http://www.itajuba.mg.gov.br/secut/cidad e.php>. Acesso em: mar. 2016.

Itajubá (MG). Feira Agroecológica e Cultural de Itajubá abre espaço para apresentações musicais. Disponível em: <http://www.itajuba.mg.gov.br/noticias.php ?id=10239>. Acesso em: 23 mar. 2018.

Lemos, P.F. I. Resíduos sólidos e responsabilidade civil pós-consumo. 2 . ed. rev., atual. e ampl. São Paulo: RT, 2012.

MMA - Ministério do Meio Ambiente. Planos Municipais de Gestão Integrada de Resíduos Sólidos. Disponível em: <http://www.mma.gov.br/cidadessustentaveis/residuos-solidos/instrumentosda-politica-de-residuos/planos-municipaisde-gest $\%$ C3\%A3o-integrada-deres\%C3\%ADduos-s\%C3\%B3lidos>. Acesso em: 23 mar. 2018. 
Moura, C. Consórcio Intermunicipal dos Municípios da Microrregião do Alto Sapucaí para Aterro Sanitário (CIMASAS). Itajubá: 2014. Disponível em: <http://abesdn.org.br/eventos/seminario_residuos_solid os/Paineis_SNRS/Painel7/72.pdf>. Acesso em: 23 maio 2018.

Pinheiro. M. V. Avaliação técnica e histórica das enchentes em Itajubá/MG. Itajubá: Universidade Federal de Itajubá, 2005. (Dissertação de mestrado). Disponível em: <http://www.professoralexandre.unifei.edu. br/Mestrado/Mario.pdf>. Acesso em: 24 abr. 2018.

Romani, A. P. Agregando valor social e ambiental. In: Segala, K. (Org.). Mecanismo de desenvolvimento limpo aplicado a resíduos sólidos. Rio de Janeiro: IBAM, 2007.

Sachs, I. Ecodesenvolvimento: crescer sem destruir. São Paulo: Vértice, 1986.

Senado. Senadores aprovam prorrogação do prazo para fechamento dos lixões. 2015. Disponível em: <http://www12.senado. leg.br/noticias/materias/2015/07/01/senad ores-aprovam-prorrogacao-do-prazo-parafechamento-dos-lixoes>. Acesso em: 11 set. 2017.

Soares, L. G. C; Salgueiro, A. A; Gazineu, M. H. P. Educação ambiental aplicada aos resíduos sólidos na Cidade de Olinda, Pernambuco: um estudo de caso. Revista Ciência e Tecnologia, Ano 1, n. 1, 2007. Disponível em: <http://www.unicap.br/revistas/revista_e/a rtigo5.pdf>. Acesso em: 30 mar. 2016.
Tenório, F. G. Projeto Cidadania e Municipalidade. Revista de Administração Pública, v. 31, n. 4, p. 293-298, 1997. Disponível em: <http://bibliotecadigital.fgv. br/ojs/index.php/rap/article/view/7896>. Acesso em: 30 out. 2017.

Tenório. F. G. (Org.). Cidadania e desenvolvimento local. Ijuí: Editora Unijuí, 2007.

UNIFEI - Universidade Federal de Itajubá. Regimento Geral aprovado na 1a Reunião Extraordinária da Congregação, de 09 de fevereiro de 2004. Disponível em: <http://www.unifei.edu.br/files/REGIMENT 0\%20GERAL.pdf>. Acesso em: 23 maio 2018.

UNIFEI - Universidade Federal de Itajubá. Estatuto da UNIFEI. Aprovado pelo Ministério da Educação - Portaria no 1.084 , de 23 de dezembro de 2015, publicado no Diário Oficial da União de 24 de dezembro de 2015. Disponível em: <https://2015.unifei. edu.br/files/anexos/Estatuto\%20da\%20UNI FEI\%20-\%200ficial\%20-\%202015.pdf>. Acesso em: 23 maio 2018.

Informação da Licença: Este é um artigo Open Access distribuído sob os termos da Licença Creative Commons Attribution, que permite uso irrestrito, distribuição e reprodução em qualquer meio, desde que a obra original seja devidamente citada. 